\title{
Splice Strength of Conventional and High Relative Rib Area Bars in Normal and High-Strength Concrete
}

\author{
by Jun Zuo and David Darwin
}

\begin{abstract}
The effects of concrete strength, coarse aggregate quantity and type, and reinforcing bar geometry on splice strength are evaluated. Results for 64 splice specimens with reinforcing bars with relative rib areas (ratio of projected rib area normal to bar axis to the product of the nominal bar perimeter and the center-to-center rib spacing) ranging from 0.069 to 0.141 , concrete strengths ranging from 4250 to $15,650 \mathrm{psi}(29$ to $108 \mathrm{MPa}$ ), and quantities of limestone and basalt coarse aggregate ranging from 1586 to $1908 \mathrm{lb} / \mathrm{yd} \mathrm{d}^{3}$ (941 to $1132 \mathrm{~kg} / \mathrm{m}^{3}$ ) are reported. The results are combined with the ACI Committee 408 database to develop design equations for development and splice length, which are then compared with the design criteria in ACI 318-99.

For splices not confined by transverse reinforcement, the 1/4 power of compressive strength $\mathrm{f}_{\mathrm{c}}^{\prime}$ best characterizes the effect of concrete strength on splice strength. $\mathrm{f}_{\mathrm{c}}^{\prime 3 / 4}$ characterizes the effect of concrete strength on the additional splice strength provided by transverse reinforcement. The splice strength of bars confined by transverse reinforcement increases with an increase in relative rib area and bar diameter. The use of stronger coarse aggregate results in an increase in splice strength for bars both with and without confining reinforcement. For splices confined by transverse reinforcement, the higher the quantity of coarse aggregate, the greater the contribution of transverse reinforcement to splice strength. The expressions characterizing the splice strength of reinforcing bars accurately represent the development/splice strength of bottom-cast uncoated bars as a function of member geometry, concrete strength, relative rib area, bar size, and confinement, provided by both concrete and transverse reinforcement. The new design expressions are superior to the design criteria in ACI 318-99 in terms of both safety and economy. The criteria in ACI 318-99 for developed bars and Class A splices are unconservative for No. 6 (No. 19) and smaller bars.
\end{abstract}

Keywords: bond; deformed reinforcement; splice; stirrup; tie.

\section{INTRODUCTION}

Concrete properties have a significant effect on the bond strength between reinforcing bars and concrete. Azizinamini et al. $(1993,1995)$ studied the effect of high concrete strength on bond using beam splice tests. The test results indicated that the average bond stress at failure, normalized with respect to the square root of concrete compressive strength $\sqrt{f_{c}^{\prime}}$, decreases with an increase in compressive strength. The rate of decrease becomes more pronounced as the splice length increases. Azizinamini et al. noted that the bearing capacity of concrete (related to $f_{c}^{\prime}$ ) increases more rapidly than tensile strength (related to $\sqrt{ } f_{c}^{\prime}$ ) as compressive strength increases. For high-strength concrete, the higher bearing capacity prevents crushing of the concrete in front of the bar ribs (as occurs for normal strength concrete), which reduces local slip. They concluded that, because of the reduced slip, fewer ribs transfer load between the steel and the concrete, which increases the local tensile stresses and initiates a splitting failure in the concrete prior to achieving a uniform distribution of the bond force. Because of the brittle nature of these failures, they recommended that a minimum quantity of stirrups be used for bars spliced or developed in high-strength concrete.

Esfahani and Rangan (1996) investigated the influence of concrete strength on bond using both beam-end and splice tests. No confining transverse reinforcement was used. They observed that the extent of concrete crushing in front of ribs varied depending on concrete strength. As concrete strength increased, the degree of crushing decreased, with no concrete crushing observed for $f_{c}^{\prime}$ greater than $11,000 \mathrm{psi}(75 \mathrm{MPa})$. In contrast to Azizinamini et al. $(1993,1995)$, they found that the average bond stress at failure, normalized with respect to the $\sqrt{f_{c}^{\prime}}$, was higher for high-strength concrete than for normal strength concrete.

In work that preceded the current effort, Darwin et al. (1996a) noted that, for normal strength concretes, higherstrength coarse aggregates can increase the contribution of transverse reinforcement to bond strength by up to $45 \%$. The scope of that study did not cover the effect of aggregate properties on bond in members without transverse reinforcement or the effect of aggregate quantity.

This paper describes the continuation of a study to improve the development characteristics of reinforcing steel by accurately characterizing the development and splice behavior of current reinforcing bars and modifying the deformation characteristics of bars to obtain improved bond strength. Earlier work in the study (Darwin and Graham 1993; Darwin et al. 1996a, 1996b) established that an increase in the relative rib area of reinforcing bars $R_{r}$ (ratio of projected rib area normal to bar axis to the product of the nominal bar perimeter and the center-to-center rib spacing) increases the bond strength between reinforcing steel and concrete for bars confined by transverse reinforcement. The earlier work also demonstrated that an increase in $R_{r}$ increases the bond strength of epoxy-coated reinforcement, both with and without confining steel.

\section{RESEARCH SIGNIFICANCE}

The principal goals of the work reported in this paper are to gain a better understanding of the effect of concrete properties on bond strength, to better understand the behavior of high relative rib area bars over the full range of concrete strengths now used in practice, and to develop a design expression that accurately represents the bond strength of reinforcing bars as a function of the geometric and material properties of the concrete member and the reinforcing bars.

ACI Structural Journal, V. 97, No. 4, July-August 2000.

MS No. 99-173 received August 2, 1999, and reviewed under Institute publication policies. Copyright (C 2000, American Concrete Institute. All rights reserved, including the making of copies unless permission is obtained from the copyright proprietors. Pertinent discussion will be published in the May-June 2001 ACI Structural Journal if received by January 1,2001 . 
ACI member Jun Zuo is a structural engineer with Constructive Engineering Design, Kansas City, Mo. He received a BS in architectural engineering from Tongji University, China, and an MS and PhD in civil engineering from the University of Kansas, Lawrence, Kan.

David Darwin, FACI, is the Deane E. Ackers Professor of Civil Engineering and Director of the Structural Engineering and Materials Laboratory at the University of Kansas. He is a past member of the Board of Direction and the Technical Activities Committee and is past-president of the Kansas Chapter of ACI. He is also past-chairman of the Publications Committee and the Concrete Research Council, and a member and past-chairman of ACI Committee 224, Cracking. He chairs the TAC Technology Transfer Committee and ACI Committee 408, Bond and Development of Reinforcement, and serves on ACI Committees 446, Fracture Mechanics, and Joint ACI-ASCE Committees 445, Shear and Torsion; and 447, Finite Element Analysis of Reinforced Concrete Structures. He is a recipient of the Arthur R. Anderson and ACI Structural Research Awards.

Only uncoated reinforcement is covered. The research is significant because it demonstrates that concrete strength has a much greater effect on the additional splice strength provided by transverse reinforcement than it does on the splice strength of bars not confined by transverse reinforcement. The paper also demonstrates that increases in aggregate strength and quantity result in higher splice strengths. Design expressions developed based on analyses of the test results and a large international database represent splice/ development length as a function of concrete strength, relative rib area, bar size, and confinement provided by both concrete and transverse reinforcement. Of major significance is the observation that the design criteria in ACI 318-99 for developed bars and Class A splices are unconservative for No. 6 (No. 19) and smaller bars. Full details of the study are presented by Zuo and Darwin (1998).

\section{EXPERIMENTAL PROGRAM}

The test program consisted of 64 beam splice specimens containing uncoated, bottom-cast bars; 41 specimens had splices that were confined by stirrups, and 23 specimens had splices that were not confined by stirrups. Ten deformation patterns were evaluated. Reinforcing bars ranged in size from No. 5 to 11 (No. 16 to 36), with relative rib areas ranging from 0.69 to 0.141 . Normal and high-strength concretes were manufactured with both limestone and basalt coarse aggregates. Concrete strengths ranged from 4,250 to $15,650 \mathrm{psi}$ (29 to $108 \mathrm{MPa}$ ).

\section{Test specimens}

The splice specimens (Fig. 1) were $16 \mathrm{ft}$ (4.9 m) long, with nominal widths of 12 or $18 \mathrm{in}$. (305 or $460 \mathrm{~mm}$ ) and a nominal depth of 15.5 or 16 in. (395 or $405 \mathrm{~mm}$ ). Splice lengths ranged from 16 to $40 \mathrm{in}$. (405 to $1020 \mathrm{~mm}$ ). The beams contained two or three spliced bars (Fig. 1(a)) located in the constant moment region of simply supported test specimens. The beams were tested in an inverted position (Fig. 1(b)). Actual member dimensions are given in Table 1.

\section{Materials}

Reinforcing steel-The reinforcing bars met the requirements of ASTM A 615. Ten deformation patterns were evaluated, including four conventional patterns, designated $8 \mathrm{C} 0 \mathrm{~A}, 8 \mathrm{N0}, 11 \mathrm{~N} 0$, and 11B0, and six experimental patterns, designated $5 \mathrm{C} 3,8 \mathrm{C} 1,8 \mathrm{~F} 1,8 \mathrm{~N} 1,8 \mathrm{~N} 3$, and $11 \mathrm{~F} 3$ (refer to Darwin et al. (1996a) for photographs of the deformation patterns). In the bar designations, the first number of the designation (one or two digits) is the bar size (customary units); the middle letter identifies the manufacturer; the trailing number identifies the deformation pattern; and a last letter is used if bars with the same deformation pattern were pro-
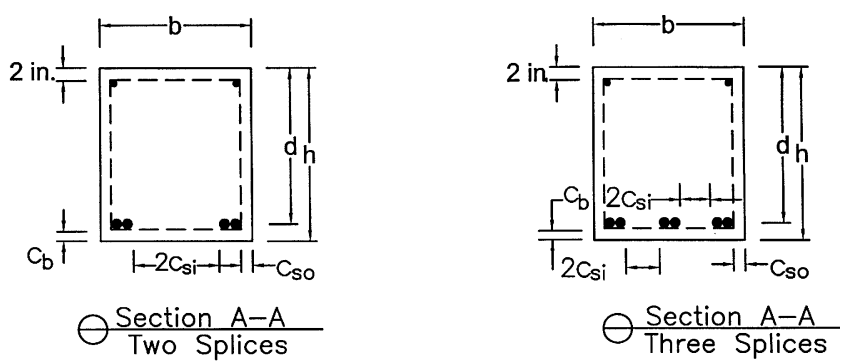

(a)

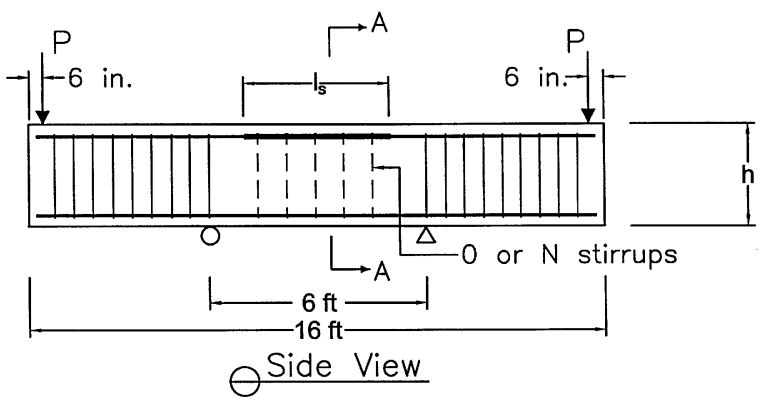

(b)

Fig. 1-Beam splice specimens: (a) beam configuration as cast; and (b) test setup (Note: $1 \mathrm{in} .=25.4 \mathrm{~mm} ; 1 \mathrm{ft}=305 \mathrm{~mm}$ ).

duced from different heats of steel. The relative rib areas range from 0.069 to 0.085 for the conventional bars and from 0.101 to 0.141 for high $R_{r}$ bars. The reinforcing bars used as transverse reinforcement also met the requirements of ASTM A 615. Bar properties are given in Table 2.

Concrete-Six concrete mixtures were used to study the effects of concrete strength and type and quantity of coarse aggregate on splice strength. The mixtures are designated as NNL, NHL, HNL, HHL, NNB, and HHB, in which the first letter indicates the concrete strength, $\mathrm{N}=$ normal strength $\left(f_{c}^{\prime}<8000 \mathrm{psi}[55 \mathrm{MPa}]\right)$, and $\mathrm{H}=$ high strength $\left(f_{c}^{\prime} \geq 8000\right.$ psi [55 MPa]); the second letter indicates the quantity of coarse aggregate, $\mathrm{N}=$ normal (1586 to $1661 \mathrm{lb} / \mathrm{yd}^{3}$ [941 to $\left.\left.985 \mathrm{~kg} / \mathrm{m}^{3}\right]\right)$, and $\mathrm{H}=$ high $\left(1803\right.$ to $1908 \mathrm{lb} / \mathrm{yd}^{3}$ [1070 to $\left.1132 \mathrm{~kg} / \mathrm{m}^{3}\right]$ ); and the last letter indicates the type of coarse aggregate, $\mathrm{L}=$ limestone, and $\mathrm{B}=$ basalt. The limestone and basalt have compressive strengths of approximately 15,000 and 50,000 psi (103 and $345 \mathrm{MPa}$ ), respectively.

Concrete strengths ranged from 4250 to 6300 psi (29.3 to $43.4 \mathrm{MPa}$ ) for normal-strength concrete, and from 8370 to $15,650 \mathrm{psi}$ (57.7 to $107.9 \mathrm{MPa}$ ) for high-strength concrete. Compressive strength was determined based on the average of at least three $6 \times 12$ in. $(150 \times 300 \mathrm{~mm})$ cylinders for strengths lower than $12,500 \mathrm{psi}(86 \mathrm{MPa})$ and at least three $4 \times 8$ in. (100 x $200 \mathrm{~mm}$ ) cylinders for higher-strength concrete. Test ages ranged from 7 to 135 days. Mixture proportions and concrete properties are summarized in Table A.1 of Appendix A.

\section{Test procedure}

The splice specimens were tested as shown in Fig. 1(b). Loads were applied at the ends of the cantilevered regions.

\footnotetext{
*The Appendix is available in xerographic or similar form from ACI headquarters, where it will be kept permanently on file, at a charge equal to the cost of reproduction plus handling at the time of request.
} 
Table 1-Splice specimen properties and test results

\begin{tabular}{|c|c|c|c|c|c|c|c|c|c|c|c|c|c|c|c|c|c|}
\hline $\begin{array}{l}\text { Specimen no. and } \\
\text { concrete }^{*}\end{array}$ & $\begin{array}{c}\text { Bar } \\
\text { esignation }\end{array}$ & $n$ & $l_{s}$, in. & $b$, in. & $h$, in. & $d_{b}$, in. & $c_{s o}$, in. & $c_{s i}$, in. & $c_{b}$, in. & $d$, in. & $f_{c}^{\prime}, \mathrm{psi}$ & $N$ & $d_{s}$, in. & $f_{y t}, \mathrm{ksi}$ & $P$, kips & $M_{u}, \mathrm{k}$-in. & $f_{s},{ }^{\dagger} \mathrm{ksi}$ \\
\hline $19.1 \mathrm{NNL}$ & $8 \mathrm{~N} 3$ & 3 & 36 & 18.14 & 16.16 & 1.000 & 1.954 & 1.930 & 1.961 & 13.66 & 4250 & 0 & - & - & 38.18 & 2094.9 & 73.51 \\
\hline $19.3 \mathrm{NNL}$ & $8 \mathrm{~N} 3$ & 3 & 30 & 18.10 & 16.07 & 1.000 & 2.063 & 1.898 & 1.903 & 13.62 & 4250 & 3 & 0.375 & 64.55 & 7.02 & 2030.7 & 71.43 \\
\hline $20.1 \mathrm{NNL}$ & $11 \mathrm{~F} 3$ & 3 & 40 & 18.05 & 16.20 & 1.410 & 2.008 & 1.313 & 1.840 & 13.61 & 5080 & 8 & 0.500 & 84.70 & 69.84 & 3805.4 & 71.08 \\
\hline $20.3 \mathrm{NNL}$ & $11 \mathrm{~F} 3$ & 3 & 40 & 18.07 & 16.15 & 1.410 & 2.000 & 1.313 & 1.822 & 13.58 & 5080 & 5 & 0.500 & 84.70 & 67.30 & 3668.2 & 68.52 \\
\hline $20.6 \mathrm{NNL}$ & $8 \mathrm{~N} 3$ & 3 & 40 & 12.08 & 15.60 & 1.000 & 1.516 & 0.672 & 1.300 & 13.76 & 5080 & 0 & - & - & 29.61 & 1621 & 57.15 \\
\hline $21.1 \mathrm{NNL}$ & $8 \mathrm{~N} 3$ & 3 & 24 & 12.05 & 15.66 & 1.000 & 1.766 & 0.484 & 1.470 & 13.65 & 4330 & 6 & 0.625 & 62.98 & 37.27 & 2032.6 & 73.88 \\
\hline $21.3 \mathrm{NNL}$ & $8 \mathrm{~N} 3$ & 3 & 25 & 12.10 & 16.13 & 1.000 & 1.655 & 0.578 & 1.492 & 13.65 & 4330 & 5 & 0.625 & 62.98 & 38.43 & 2095.8 & 76.25 \\
\hline $21.5 \mathrm{NNL}$ & $8 \mathrm{~N} 3$ & 2 & 25 & 12.14 & 15.54 & 1.000 & 1.641 & 2.219 & \begin{tabular}{|l|}
1.421 \\
\end{tabular} & 13.58 & 4330 & 5 & 0.500 & 64.92 & 26.67 & 1460.3 & 77.35 \\
\hline 23a.1 HHL & $8 \mathrm{~N} 3$ & 3 & 21 & 18.28 & 16.09 & 1.000 & 2.164 & 1.852 & 1.931 & 13.62 & 9080 & 4 & 0.375 & 71.25 & 42.51 & 2325.9 & 78.87 \\
\hline 23a.4 HHL & $8 \mathrm{~N} 3$ & 3 & 21 & 18.13 & 16.10 & 1.000 & 2.008 & 1.898 & 1.930 & 13.69 & 9080 & 4 & 0.375 & 71.25 & 42.88 & 2346.1 & 79.15 \\
\hline 23a.5 HHL & $8 \mathrm{~N} 3$ & 2 & 22 & 18.19 & 16.16 & 1.000 & 2.000 & 1.891 & 1.938 & 13.63 & 9320 & 0 & - & - & 22.72 & 1247.9 & 62.24 \\
\hline 23a.6 HHL & $8 \mathrm{~N} 3$ & 2 & 29 & 12.24 & 16.11 & 1.000 & 2.031 & 1.875 & \begin{tabular}{|l|}
1.919 \\
\end{tabular} & 13.67 & 9320 & 0 & - & - & 27.25 & 1492.5 & 75.47 \\
\hline 23b.1 HHL & $8 \mathrm{~N} 3$ & 3 & 18 & 12.15 & 16.22 & 1.000 & 1.469 & 0.711 & 1.951 & 13.73 & 8370 & 5 & 0.500 & 64.92 & 41.87 & 2281.3 & 79.04 \\
\hline 23b.3 HHL & $8 \mathrm{~N} 3$ & 2 & 20 & 18.23 & 16.32 & 1.000 & 3.032 & 3.859 & 3.057 & 12.72 & 8370 & 0 & - & - & 24.02 & 1328.1 & 71.64 \\
\hline 23b.5 HHL & 11F3 & 2 & 25 & 12.03 & 16.24 & 1.410 & 2.032 & 1.125 & 1.939 & 13.56 & 4500 & 5 & 0.500 & 64.92 & 32.37 & 1954.3 & 54.80 \\
\hline $24.1 \mathrm{NNL}$ & $8 \mathrm{~N} 1$ & 2 & 32 & 12.14 & 16.12 & 1.000 & 2.000 & 1.875 & 1.903 & 13.69 & 4300 & 0 & - & - & 21.54 & 1184.9 & 61.91 \\
\hline $25.1 \mathrm{NNL}$ & $5 \mathrm{C} 3$ & 3 & 17 & 12.19 & 16.27 & 0.625 & 1.985 & 1.023 & 1.556 & 14.37 & 4490 & 0 & - & - & 14.59 & 808.01 & 63.72 \\
\hline $26.3 \mathrm{NNL}$ & $8 \mathrm{~N} 1$ & 3 & 40 & 12.11 & 16.19 & 1.000 & 1.547 & 0.652 & 1.889 & 13.78 & 4960 & 0 & - & - & 32.34 & 1769.4 & 62.51 \\
\hline $26.5 \mathrm{NNL}$ & $8 \mathrm{NO}$ & 3 & 40 & 12.15 & 16.17 & 1.000 & 1.500 & 0.684 & 1.891 & 13.75 & 4960 & 0 & - & - & 33.21 & 1816.4 & 64.35 \\
\hline $27.2 \mathrm{HHL}$ & $8 \mathrm{NO}$ & 3 & 23 & 12.12 & 15.52 & 1.000 & 2.000 & \begin{tabular}{|l|}
0.477 \\
\end{tabular} & \begin{tabular}{|l|}
1.415 \\
\end{tabular} & 13.71 & 10810 & 6 & 0.375 & 64.92 & 42.70 & 2325.7 & 78.52 \\
\hline $27.4 \mathrm{HHL}$ & $8 \mathrm{NO}$ & 3 & 18 & 12.15 & 15.50 & 1.000 & 2.000 & 0.457 & 1.442 & 13.54 & 10810 & 5 & 0.500 & 64.92 & 40.78 & 2221.8 & 77.21 \\
\hline 27.6 & & 3 & 18 & 18.12 & 15.62 & 1.000 & 4.032 & 0.930 & 1.442 & 13.65 & 10810 & 4 & 0.500 & 64.92 & 43.02 & 2352.5 & 8.42 \\
\hline $28.1 \mathrm{HHL}$ & $11 \mathrm{~F} 3$ & 2 & 25 & 11.71 & 16.07 & 1.410 & 2.188 & 0.766 & 1.900 & 13.42 & 12,610 & 5 & 0.375 & 71.25 & 48.63 & 2646.2 & 71.23 \\
\hline $28.3 \mathrm{HHL}$ & $11 \mathrm{~F} 3$ & 3 & 28 & 18.10 & 16.09 & 1.410 & 2.172 & 1.242 & 1.901 & 13.45 & 12,610 & 4 & 0.375 & 71.25 & 68.89 & 3751.7 & 67.03 \\
\hline $28.5 \mathrm{HHL}$ & $11 \mathrm{~F} 3$ & 2 & 30 & 18.09 & 16.20 & 1.410 & 1.977 & 4.031 & 1.999 & 13.45 & 12,610 & 0 & - & - & 35.40 & 1944 & 50.89 \\
\hline $29.2 \mathrm{HHB}$ & & 3 & 20 & 12.14 & 15.60 & 1.000 & 1.875 & 484 & 1.478 & 13.60 & 10,620 & 5 & \begin{tabular}{|l|}
0.375 \\
\end{tabular} & 71.25 & 46.07 & 2507.7 & 83.65 \\
\hline $29.4 \mathrm{HHB}$ & $8 \mathrm{NO}$ & 3 & 18 & 12.17 & 15.60 & 1.000 & 1.938 & 0.492 & 1.418 & 13.66 & 10,620 & 6 & 0.375 & 71.25 & 41.94 & 2284.4 & 77.96 \\
\hline $29.6 \mathrm{HHB}$ & $8 \mathrm{NO}$ & 3 & 16 & 18.17 & 15.65 & 1.000 & 3.906 & 0.980 & 1.414 & 13.71 & 10,620 & 4 & 0.375 & 71.25 & 42.25 & 2310.8 & 77.72 \\
\hline $30.1 \mathrm{HHB}$ & & 2 & 25 & 12.19 & 16.15 & 1.410 & 2.375 & 0.688 & 1.891 & 13.51 & 13,220 & 3 & 0.375 & 71.25 & 45.63 & 2484.8 & 66.07 \\
\hline $30.3 \mathrm{HHB}$ & $11 \mathrm{~F} 3$ & 3 & 28 & 18.02 & 16.11 & 1.410 & 1.953 & 1.273 & 1.889 & 13.47 & 13,220 & 2 & 0.375 & 71.25 & 68.97 & 3755.7 & 66.88 \\
\hline $30.5 \mathrm{HHB}$ & $11 \mathrm{~F} 3$ & 2 & 30 & 18.12 & 16.15 & 1.410 & 2.063 & 4.016 & 1.956 & 13.44 & 13,220 & 0 & - & - & 46.72 & 2554.9 & 66.95 \\
\hline $31.3 \mathrm{HHB}$ & $8 \mathrm{NO}$ & 2 & 16 & 12.15 & 15.48 & 1.000 & 1.969 & 1.938 & 1.438 & 13.52 & 12,890 & 2 & 0.375 & 71.25 & 23.39 & 1282.4 & 65.21 \\
\hline $31.5 \mathrm{HHB}$ & & 3 & 22 & 12.26 & 15.58 & 000 & 1.828 & 508 & 1.494 & 13.56 & 12,890 & 0 & - & - & 2.73 & 7.4 & 1.43 \\
\hline $31.6 \mathrm{HHB}$ & $8 \mathrm{C} 0 \mathrm{~A}$ & 3 & 22 & 12.17 & 15.49 & 1.000 & 1.719 & 0.539 & 1.492 & 13.44 & 12,890 & 0 & - & - & 33.47 & 1826.9 & 63.42 \\
\hline $32.1 \mathrm{HHB}$ & $11 \mathrm{~F} 3$ & 2 & 32 & 12.17 & 16.17 & 1.410 & 2.000 & 0.984 & 1.904 & 13.52 & 14,400 & 0 & - & - & 43.86 & 2390.4 & 63.33 \\
\hline $32.2 \mathrm{HHB}$ & 11B0 & 2 & 32 & 12.14 & 16.16 & 1.410 & 2.000 & 1.063 & 1.916 & 13.51 & 14,400 & 0 & - & - & 42.55 & 2319.3 & 61.49 \\
\hline $32.3 \mathrm{HHB}$ & $11 \mathrm{~F} 3$ & 2 & 32 & 18.14 & 16.15 & 1.410 & 1.969 & 4.016 & 1.947 & 13.45 & 14,400 & 0 & - & - & 42.41 & 2322.6 & 60.64 \\
\hline $32.4 \mathrm{HHB}$ & $11 \mathrm{~B} 0$ & 2 & 28 & 18.20 & 16.17 & 1.410 & 2.031 & 4.047 & 1.935 & 13.50 & 14,400 & 0 & - & - & 42.85 & 2345.7 & 61.01 \\
\hline $33.2 \mathrm{NHL}$ & $8 \mathrm{COA}$ & 3 & 18 & 12.10 & 16.12 & 1.000 & 1.953 & 0.395 & 1.913 & 13.66 & 5360 & 6 & 0.500 & 64.92 & 31.69 & 1731.7 & 61.42 \\
\hline $33.3 \mathrm{NHL}$ & N1 & 3 & 18 & 18.14 & 16.13 & 1.000 & 2.070 & 1.918 & 1.969 & 13.63 & 5360 & 4 & 0.375 & 71.25 & 30.27 & 1664.6 & 57.60 \\
\hline $33.4 \mathrm{NHL}$ & $8 \mathrm{C} 0 \mathrm{~A}$ & 3 & 18 & 18.12 & 16.13 & 1.000 & 2.063 & 1.914 & 1.936 & 13.64 & 5360 & 4 & 0.375 & 71.25 & 30.67 & 1686.7 & 58.32 \\
\hline $33.6 \mathrm{NHL}$ & $8 \mathrm{C} 0 \mathrm{~A}$ & 2 & 22 & 12.17 & 16.26 & 1.000 & 2.094 & 1.688 & 1.891 & 13.82 & 5230 & 2 & 0.375 & 71.25 & 20.57 & 1131.6 & 57.94 \\
\hline $34.3 \mathrm{NHL}$ & $8 \mathrm{C} 0 \mathrm{~A}$ & 3 & 24 & 18.12 & 16.02 & 1.000 & 2.080 & 1.844 & 1.981 & 13.49 & 5440 & 0 & - & - & 30.64 & 1685.2 & 58.94 \\
\hline $35.1 \mathrm{NNL}$ & $8 \mathrm{~F} 1$ & 2 & 20 & 12.08 & 16.17 & 1.000 & 1.453 & 2.375 & 1.938 & 13.69 & 5330 & 5 & \begin{tabular}{|l|}
0.375 \\
\end{tabular} & 71.25 & 24.08 & 1320.9 & 68.44 \\
\hline $35.3 \mathrm{NNL}$ & $8 \mathrm{C} 0 \mathrm{~A}$ & 2 & 20 & 12.08 & 16.07 & 1.000 & 1.500 & 2.266 & 1.920 & 13.60 & 5330 & 5 & 0.375 & 71.25 & 21.58 & 1185.7 & 61.77 \\
\hline $36.3 \mathrm{NHL}$ & $8 \mathrm{COA}$ & 3 & 26 & 18.17 & 16.10 & 1.000 & 2.016 & 1.836 & 2.000 & 13.55 & 5060 & 0 & - & - & 32.68 & 1796.3 & 62.78 \\
\hline $37.4 \mathrm{NNL}$ & $8 \mathrm{~F} 1$ & 3 & 21 & 12.07 & 15.51 & 1.000 & 2.000 & 0.484 & 1.503 & 13.47 & 4800 & 7 & 0.500 & 64.92 & 37.02 & 2018.7 & 73.78 \\
\hline $38.2 \mathrm{NNL}$ & $8 \mathrm{C} 0 \mathrm{~A}$ & 3 & 26 & 18.17 & 16.14 & 1.000 & 2.125 & 1.844 & 2.075 & 13.51 & 5080 & 0 & - & - & 31.41 & 1727.8 & 60.51 \\
\hline 39.2 HHB & $8 \mathrm{C} 1$ & 3 & 16 & 12.18 & 15.48 & 1.000 & 1.906 & 0.516 & 1.475 & 13.49 & 14,450 & 4 & 0.375 & 71.25 & 38.59 & 2103.2 & 69.74 \\
\hline $39.3 \mathrm{HHB}$ & $8 \mathrm{NO}$ & 3 & 16 & 12.17 & 15.45 & 1.000 & 1.891 & \begin{tabular}{|l|}
0.488 \\
\end{tabular} & \begin{tabular}{|l|}
1.477 \\
\end{tabular} & 13.45 & 14,450 & 4 & \begin{tabular}{|l|}
0.375 \\
\end{tabular} & 71.25 & 41.43 & 2256.5 & 77.96 \\
\hline $39.6 \mathrm{HHB}$ & $8 \mathrm{C} 1$ & 3 & 21 & 12.19 & 15.41 & 1.000 & 1.953 & 0.508 & 1.505 & 13.59 & 14,450 & 0 & - & - & 36.10 & 1969.1 & 67.38 \\
\hline $40.1 \mathrm{HHB}$ & $11 \mathrm{~F} 3$ & 2 & 23 & 12.16 & 15.48 & 1.410 & 2.031 & 1.000 & 1.473 & 13.26 & 15,650 & 4 & 0.375 & 71.25 & 45.38 & 2470.5 & 66.60 \\
\hline $40.4 \mathrm{HHB}$ & $11 \mathrm{~N} 0$ & 2 & 23 & 12.09 & 15.52 & 1.410 & 2.000 & 1.063 & 1.451 & 13.33 & 15,650 & 4 & 0.375 & 71.25 & 40.32 & 2197.1 & 58.83 \\
\hline
\end{tabular}

*Specimen and concrete: G.P-SQA = group number (19 to 43); $\mathrm{P}=$ casting order in group $(1$ to 6$) ; \mathrm{S}=$ strength $(\mathrm{N}=$ normal, $\mathrm{H}=$ high); $\mathrm{Q}=$ aggregate quantity $(\mathrm{N}=$ normal, $\mathrm{H}=$ high); and $\mathrm{A}=$ aggregate type ( $\mathrm{L}=$ limestone, $\mathrm{B}=$ basalt $)$.

${ }^{\dagger}$ Bar stress computed using moment-curvature method if $M_{u}$ does not exceed moment capacity from moment-curvature analysis; otherwise, $f_{s}$ computed using ultimate strength method; $M_{u}$ and $f_{s}$ include effects of beam self-weight and loading system.

Note: $N=$ number of stirrups; $d_{s}=$ stirrup diameter; $f_{y t}=$ stirrup yield strength; 1 in. $=25.4 \mathrm{~mm} ; 1 \mathrm{psi}=6.89 \mathrm{kPa} ; 1 \mathrm{ksi}=6.89 \mathrm{MPa} ; 1 \mathrm{kip}=4.45 \mathrm{kN}$; and $1 \mathrm{k}$-in. $=0.113 \mathrm{kN}-\mathrm{m}$. 
Table 1 (cont.)-Splice specimen properties and test results

\begin{tabular}{c|c|c|c|c|c|c|c|c|c|c|c|c|c|c|c|c|c}
\hline $\begin{array}{c}\text { Specimen no. and } \\
\text { concrete }\end{array}$ & $\begin{array}{c}\text { Bar } \\
\text { designation }\end{array}$ & $n$ & $l_{s}$, in. & $b$, in. & $h$, in. & $d_{b}$, in. & $c_{s o}$, in. & $c_{s i}$, in. & $c_{b}$, in. & $d$, in. & $f_{c}^{\prime}, \mathrm{psi}$ & $N$ & $d_{s}$, in. & $f_{y}$, ksi & $P, \mathrm{kips}$ & $M_{u}, \mathrm{k}$-in. & $f_{s},{ }^{\dagger} \mathrm{ksi}$ \\
\hline $40.5 \mathrm{HHB}$ & $8 \mathrm{~N} 0$ & 2 & 17 & 12.11 & 16.04 & 1.000 & 2.000 & 1.875 & 1.846 & 13.67 & 15,650 & 0 & - & - & 24.00 & 1315.9 & 65.81 \\
\hline $41.1 \mathrm{HHL}$ & $8 \mathrm{~N} 3$ & 2 & 16 & 12.14 & 15.55 & 1.000 & 2.000 & 1.844 & 1.522 & 13.49 & 10,180 & 2 & 0.375 & 71.25 & 23.52 & 1289.5 & 66.16 \\
\hline $41.2 \mathrm{HHL}$ & $8 \mathrm{~N} 3$ & 3 & 16 & 12.16 & 15.53 & 1.000 & 1.875 & 0.469 & 1.515 & 13.38 & 10,180 & 4 & 0.625 & 62.98 & 44.34 & 2413.6 & 83.02 \\
\hline $41.3 \mathrm{HHL}$ & $8 \mathrm{~N} 3$ & 3 & 16 & 12.11 & 16.09 & 1.000 & 1.891 & 0.461 & 1.890 & 13.56 & 10,180 & 4 & 0.500 & 64.92 & 41.87 & 2280.9 & 79.35 \\
\hline $41.4 \mathrm{HHL}$ & $8 \mathrm{~N} 0$ & 3 & 16 & 12.20 & 15.53 & 1.000 & 1.906 & 0.484 & 1.476 & 13.40 & 10,180 & 4 & 0.625 & 62.98 & 40.28 & 2194.4 & 77.27 \\
\hline $41.6 \mathrm{HHL}$ & $8 \mathrm{C} 0 \mathrm{~A}$ & 3 & 16 & 18.22 & 16.17 & 1.000 & 2.000 & 1.875 & 1.984 & 13.63 & 10,500 & 2 & 0.375 & 71.25 & 35.26 & 1934.3 & 65.38 \\
\hline $42.1 \mathrm{HNL}$ & $8 \mathrm{~N} 0$ & 2 & 16 & 12.11 & 15.99 & 1.000 & 2.000 & 1.859 & 1.864 & 13.50 & 11,930 & 2 & 0.375 & 71.25 & 22.97 & 1260.1 & 64.32 \\
\hline $42.4 \mathrm{HNL}$ & $8 \mathrm{~N} 0$ & 3 & 16 & 12.17 & 16.09 & 1.000 & 1.906 & 0.500 & 1.829 & 13.74 & 11,930 & 4 & 0.500 & 64.92 & 38.07 & 2075.9 & 70.70 \\
\hline $42.5 \mathrm{HNL}$ & $8 \mathrm{~N} 0$ & 3 & 16 & 12.18 & 15.36 & 1.000 & 1.906 & 0.500 & 1.476 & 13.62 & 11,930 & 4 & 0.625 & 62.98 & 41.60 & 2266.0 & 77.92 \\
\hline $43.2 \mathrm{HNL}$ & $8 \mathrm{~N} 3$ & 2 & 16 & 12.06 & 16.06 & 1.000 & 2.031 & 1.875 & 1.844 & 13.68 & 11,530 & 2 & 0.375 & 71.25 & 23.49 & 1288.5 & 64.95 \\
\hline $43.3 \mathrm{HNL}$ & $8 \mathrm{~N} 3$ & 3 & 16 & 12.22 & 16.07 & 1.000 & 1.844 & 0.500 & 1.859 & 13.83 & 11,530 & 4 & 0.500 & 64.92 & 42.70 & 2326.4 & 78.81 \\
\hline $43.6 \mathrm{HNL}$ & $8 \mathrm{~N} 3$ & 3 & 16 & 12.07 & 15.48 & 1.000 & 1.891 & 0.500 & 1.492 & 13.62 & 11,530 & 4 & 0.625 & 62.98 & 45.16 & 2458.3 & 82.73 \\
\hline
\end{tabular}

*Specimen and concrete: G.P-SQA = group number (19 to 43); $\mathrm{P}=$ casting order in group (1 to 6$) ; \mathrm{S}=$ strength $(\mathrm{N}=\mathrm{normal}, \mathrm{H}=\mathrm{high}) ; \mathrm{Q}=$ aggregate quantity $(\mathrm{N}=$ normal, $\mathrm{H}=$ high); and $\mathrm{A}=$ aggregate type ( $\mathrm{L}=$ limestone, $\mathrm{B}=$ basalt $)$.

${ }^{\dagger}$ Bar stress computed using moment-curvature method if $M_{u}$ does not exceed moment capacity from moment-curvature analysis; otherwise, $f_{s}$ computed using ultimate strength method; $M_{u}$ and $f_{s}$ include effects of beam self-weight and loading system.

Note: $N=$ number of stirrups; $d_{s}=$ stirrup diameter; $f_{y t}=$ stirrup yield strength; 1 in. $=25.4 \mathrm{~mm} ; 1 \mathrm{psi}=6.89 \mathrm{kPa} ; 1 \mathrm{ksi}=6.89 \mathrm{MPa} ; 1 \mathrm{kip}=4.45 \mathrm{kN}$; and $1 \mathrm{k}$-in. $=0.113 \mathrm{kN}-\mathrm{m}$.

Table 2-Properties of reinforcing bars

\begin{tabular}{c|c|c|c|c|c|c|c|c}
\hline & & & & & \multicolumn{2}{|c}{ Rib height } & & \\
\cline { 5 - 9 } Bar designation $^{*}$ & Yield strength, ksi & Nominal diameter, in. & Weight, lb/ft & \% light or heavy & Rib spacing, in. & ASTM, in. & Average, ${ }^{\dagger}$ in. & Relative rib area \\
\hline $5 \mathrm{C} 3$ & 62.98 & 0.625 & 1.033 & $1.0 \% \mathrm{~L}$ & 0.258 & 0.047 & 0.043 & 0.141 \\
\hline $8 \mathrm{C} 0 \mathrm{~A}$ & 69.50 & 1.000 & 2.615 & $2.1 \% \mathrm{~L}$ & 0.598 & 0.066 & 0.063 & 0.085 \\
\hline $8 \mathrm{~N} 0$ & 77.96 & 1.000 & 2.594 & $2.8 \% \mathrm{~L}$ & 0.650 & 0.057 & 0.054 & 0.069 \\
\hline $8 \mathrm{C} 1$ & 67.69 & 1.000 & 2.592 & $5.3 \% \mathrm{~L}$ & 0.504 & 0.064 & 0.060 & 0.101 \\
\hline $8 \mathrm{~F} 1$ & 75.42 & 1.000 & 2.600 & $2.6 \% \mathrm{~L}$ & 0.471 & 0.078 & 0.074 & 0.140 \\
\hline $8 \mathrm{~N} 1$ & 79.70 & 1.000 & 2.733 & $2.4 \% \mathrm{H}$ & 0.441 & 0.073 & 0.068 & 0.121 \\
\hline $8 \mathrm{~N} 3$ & 80.57 & 1.000 & 2.730 & $2.2 \% \mathrm{H}$ & 0.487 & 0.072 & 0.068 & 0.119 \\
\hline $11 \mathrm{~N} 0$ & 65.54 & 1.410 & 5.157 & $2.9 \% \mathrm{~L}$ & 0.911 & 0.079 & 0.075 & 0.072 \\
\hline $11 \mathrm{~B} 0$ & 66.69 & 1.410 & 5.102 & $4.0 \% \mathrm{~L}$ & 0.825 & 0.070 & 0.066 & 0.070 \\
\hline $11 \mathrm{~F} 3$ & 77.77 & 1.410 & 5.145 & $3.2 \% \mathrm{~L}$ & 0.615 & 0.090 & 0.088 & 0.127 \\
\hline
\end{tabular}

*Bar designation: No. AAB, No. = bar size (No. 5, No. 8, or No. 11); AA = bar manufacturer and deformation pattern; B0= conventional Birmingham Steel bars; $\mathrm{C} 0=$ conventional Chapparal Steel bars; C1, C3 = new Chapparal Steel bars; N0 = conventional North Star Steel bars; F1, F3 = new Florida Steel bars; N1, N3 = new North Star Steel bars; B = letter used if bar had same deformation pattern as reported by Darwin et al. (1996a), but were produced from different steel heat.

Average rib height between longitudinal ribs.

Note: 1 in. $=25.4 \mathrm{~mm} ; 1 \mathrm{ksi}=6.89 \mathrm{MPa} ; 1 \mathrm{lb} / \mathrm{ft}=1.49 \mathrm{~kg} / \mathrm{m}$; and $1 \mathrm{mil}=0.0254 \mathrm{~mm}$.

Beams were loaded continuously at a rate of approximately 3 kips $(13.3 \mathrm{kN})$ per min until failure, with tests lasting 15 to $20 \mathrm{~min}$.

\section{SPECIMEN BEHAVIOR AND ANALYSIS OF TEST RESULTS \\ Results and observations}

Moments and maximum bar stresses in the splices at failure are given in Table 1 . The effects of beam self-weight and the weight of the loading system are included. Bar stresses are calculated using moment-curvature or ultimate strength methods, as indicated in Table 1 and described in Appendix B.

Most of the specimens failed by splitting at the tension face within the splice region. For members cast with normal strength concrete, beams with splices that were not confined by transverse stirrups failed suddenly, with a quick drop in load after the peak. Beams with splices confined by stirrups exhibited a more ductile behavior, with a slow drop in load after the peak. For members cast with high-strength concrete, similar differences were observed between members without

\footnotetext{
*The Appendix is available in xerographic or similar form from ACI headquarters, where it will be kept permanently on file, at a charge equal to the cost of reproduction plus handling at the time of request.
}

and with stirrups. The high-strength concrete beams failed in a more brittle manner than the normal-strength concrete beams.

The extent of concrete damage at the steel-concrete interface depended on the concrete strength and bar deformation pattern. Damage was more extensive near the discontinuous ends of splices. For normal strength concrete, damage was similar to that observed by Darwin et al. (1996a)—for conventional bars, the concrete crushed between the bar ribs, while for high $R_{r}$ bars, the concrete both crushed and sheared. In general, the greater the confinement provided by transverse reinforcement, the greater the damage at the interface near the discontinuous ends of the spliced bars.

For high-strength concrete specimens without stirrups in the splice region, the interface showed little or no concrete damage. For bars confined by stirrups, concrete damage at the interface was similar to that observed in normal strength concrete beams, but the damage occurred over a longer region, up to $3 / 4$ of the splice length.

In matched pairs of specimens containing conventional and high relative rib area bars confined by stirrups, the high relative rib area bars produced higher splice strengths. 
Table 3-Effect of concrete properties on splice strength of splices not confined by transverse reinforcement

\begin{tabular}{c|c|c|c|c}
\hline \multirow{2}{*}{ Concrete $^{*}$} & \multirow{2}{*}{$\begin{array}{c}\text { Number of } \\
\text { tests }\end{array}$} & \multicolumn{3}{|c}{ Test-prediction ratio $^{\dagger}$} \\
\cline { 3 - 5 } & 35 & 1.25 & 0.90 & 1.00 \\
\hline NNL & 6 & 1.06 & 0.98 & 1.01 \\
\hline NHL & 4 & 1.00 & 0.88 & 0.96 \\
\hline HHL & 2 & 1.15 & 1.06 & 1.11 \\
\hline NNB & 9 & 1.27 & 0.99 & 1.13 \\
\hline HHB & &
\end{tabular}

*Concrete designation: SQA: $\mathrm{S}=$ strength $(\mathrm{N}=$ normal, $\mathrm{H}=$ high $) ; \mathrm{Q}=$ aggregate quantity $(\mathrm{N}=$ normal, $\mathrm{H}=$ high $)$; and $\mathrm{A}=$ aggregate type $(\mathrm{L}=$ limestone, $\mathrm{B}=$ basalt $)$ ${ }^{\dagger}$ Test-predicted splice strength ratio; test strength $=A_{b} f_{s} / f_{c}^{\prime 1 / 4}$, determined from test results; predicted strength determined using Eq. (1); and predicted strengths for individual specimens presented in Table A.5 of Appendix A

\section{Evaluation of test results}

In previous work on high $R_{r}$ bars, Darwin et al. (1996a) observed that the type of coarse aggregate significantly affects splice strength for bars that are confined by stirrups. That study did not address the effect of coarse aggregate type on the splice strength of bars not confined by transverse reinforcement nor the effect of coarse aggregate quantity.

Darwin et al. (1996b) found that the 1/4 power of the concrete compressive strength $f_{c}^{\prime}$ characterizes the effect of concrete strength on splice strength for bars both confined and not confined by transverse reinforcement. The earlier studies (Darwin et al., 1996a) also showed that the additional strength provided by confining steel $T_{s}$, normalized with respect to $f_{c}^{\prime}{ }^{1 / 4}$, is a function of the effective transverse reinforcement $N A_{t r} / n$, in which $\mathrm{N}$ is the number of transverse stirrups or ties in the splice region, $A_{t r}$ is the area of each stirrup or tie crossing the potential plane of splitting adjacent to the reinforcing bars being developed or spliced, and $n$ is the number of reinforcing bars being developed or spliced along the plane of splitting. The yield strength of the transverse reinforcement was found to have no measurable effect on $T_{s}$ (Maeda et al. 1991; Sakurada et al. 1993; Azizinamini et al. 1995; and Darwin et al. 1996a, 1996b). The database used by Darwin et al., however, included only a small number of specimens made with high-strength concrete. Thus, with more data available on high-strength concrete specimens, the question arises as to whether or not the $1 / 4$ power of $f_{c}^{\prime}$ is still appropriate for characterizing the contribution of concrete strength to bond.

For the evaluations that follow, the current results are combined with those reported by Choi et al. (1991), Hester et al. (1993), and Darwin et al. (1996a) on splice specimens similar to the current NNL concrete specimens (normal strength concrete with a normal quantity of limestone coarse aggregate). Specimens 8.3 and 10.5 tested by Darwin et al. (1996a) contained NNB concrete $(B=$ Basalt). The previous test results are summarized in Tables A.2, A.3, and A.4 of Appendix A. Strength evaluations are based on the assumption that the total force in a bar at splice failure $T_{b}$ equals the sum of a concrete contribution $T_{c}$ and a transverse reinforcement (steel) contribution $T_{s}, T_{b}=T_{c}+T_{s}$.

Concrete contribution $\mathrm{T}_{\mathrm{c}}$-Using procedures described by Darwin et al. (1996b) and a database consisting of 171 specimens containing developed or spliced bars not confined by transverse reinforcement (Chinn 1955; Chamberlin 1956, 1958; Ferguson and Breen 1965; Thompson et al. 1975; Zekany et al. 1981; Choi et al. 1991; Hester et al. 1993; Rezansoff et al. 1993; Azizinamini et al. 1993; Hatfield et al. 1996; Darwin et al. 1996a; Zuo and Darwin 1998) with concrete strengths ranging from 2610 to $15,650 \mathrm{psi}$ (18.0 to $107.9 \mathrm{MPa}$ ), the ultimate bond force for bars not confined by transverse reinforcement $T_{c}$ can be expressed as (Zuo and Darwin 1998)

$$
\begin{gathered}
\frac{T_{c}}{f_{c}^{\prime 1 / 4}}=\frac{A_{b} f_{s}}{f_{c}^{\prime 1 / 4}}=\left[59.8 l_{d}\left(c_{\min }+0.5 d_{b}\right)+2350 A_{b}\right] \\
\left(0.1 \frac{c_{\max }}{c_{\min }}+0.9\right)
\end{gathered}
$$

where

$$
\begin{aligned}
& A_{b} \quad=\text { single spliced bar area, in. }{ }^{2} \text {; } \\
& f_{s} \quad=\text { bar stress at failure, psi; } \\
& f_{c}^{\prime} \quad=\text { concrete compressive strength, } \mathrm{psi} ; f_{c}^{\prime}{ }^{1 / 4} \text {, psi } \\
& l_{d} \quad=\text { splice or development length, in.; } \\
& c_{\min }, c_{\max }=\text { minimum or maximum value of } c_{S} \text {, or } \\
& c_{b}\left(c_{\max } / c_{\min } \leq 3.5\right) \text {, in.; } \\
& c_{s} \quad=\min \left(c_{s i}+0.25 \text { in., } c_{s o}\right) \text { in.; } \\
& c_{s i} \quad=1 / 2 \text { of clear spacing between bars, in.; } \\
& c_{s o}, c_{b} \quad=\text { side or bottom cover of reinforcing bars, in.; } \\
& \text { and } \\
& d_{b} \quad=\text { bar diameter, in }
\end{aligned}
$$

This expression differs somewhat from that obtained in the earlier studies (Darwin et al. 1996a, 1996b) in that the coefficient for $l_{d}$ has decreased from 63 to 59.8 and the coefficient for $A_{b}$ has increased from 2130 to 2350 . As before, $f_{c}^{\prime}{ }^{1 / 4}$ best represents the effect of compressive strength bond strength. The database used to establish Eq. (1) includes an additional 38 beams, compared to that used by Darwin et al. (1996b), and an increase from 7 to $19 \%$ in the portion of the tests representing high-strength concrete $\left(f_{c}^{\prime}>8000 \mathrm{psi}[55 \mathrm{MPa}]\right)$. A comparison of the test and predicted strengths for the beams used to establish Eq. (1) is presented in Table A.5 of Appen$\operatorname{dix} \mathrm{A}^{*}$. The mean test-prediction ratio is 1.00 , with a coefficient of variation (COV) of 0.104 , compared to 1.00 and 0.107 obtained by Darwin et al. (1996b) for the smaller database. Test-prediction ratios based on Eq. (1) are used to evaluate the effects of concrete properties on splice strength.

\section{Effects of concrete properties on splices without transverse reinforcement}

Specimens without stirrups within the splice region include 35 containing NNL concrete (nine from the current study, 12 from Darwin et al. [1996a], eight from Choi et al. [1991], and seven from Hester et al. [1993]), two containing NNB concrete (Darwin et al. 1996a), six containing NHL concrete, four containing HHL concrete, and nine containing HHB concrete.

Effect of coarse aggregate-Table 3 summarizes the range and mean of the test-prediction ratios for the splices not confined by stirrups. The results show no measurable difference in the test-prediction ratios for concrete containing the same type of coarse aggregate, regardless of coarse aggregate content or concrete strength, but do show a difference based on the type of coarse aggregate. The average test-prediction ratios range from 0.96 to 1.01 for the concretes containing limestone, compared with 1.10 and 1.13 for the concretes containing basalt. This observation can be explained based on studies by Kozul and Darwin (1997) and Barham and Darwin (1999), using the same coarse aggregates, which show that concretes containing basalt yield only slightly higher flexural

\footnotetext{
*The Appendix is available in xerographic or similar form from ACI headquarters, where it will be kept permanantly on file, at a charge equal to the cost of reproduction plus handling at the time of request.
} 


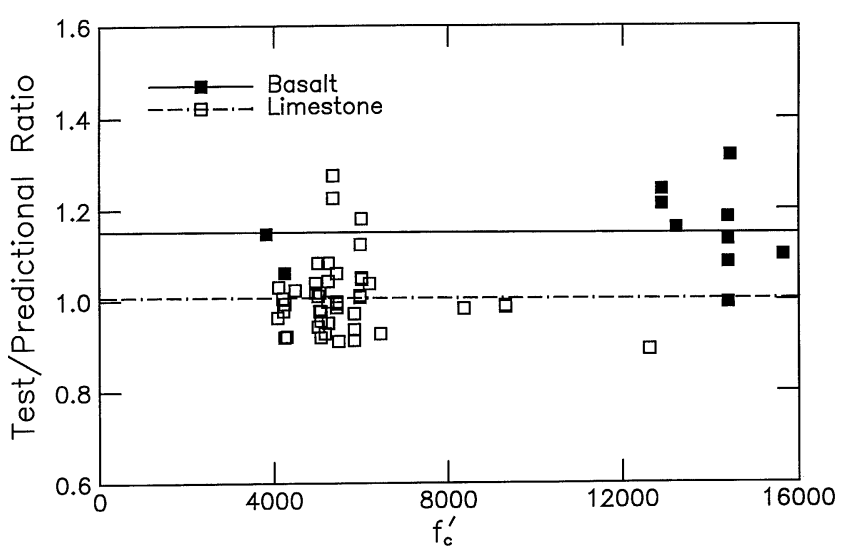

Fig. 2-Test-prediction ratio versus concrete compressive strength $\mathrm{f}_{\mathrm{c}}^{\prime}$ for splices not confined by transverse reinforcement in concrete containing basalt and limestone coarse aggregates, using dummy variable analysis based on type of coarse aggregate $(1 \mathrm{psi}=6.89 \mathrm{kPa})$.

strengths but significantly higher fracture energies (more than two times higher) than concrete of similar compressive strength containing limestone for all compressive strengths evaluated (2920 to 14,320 psi [20 to $99 \mathrm{MPa}$ ]). The higher fracture energy provided by the basalt results in an increased resistance to crack propagation that delays splitting failure and increases splice strength.

Effect of concrete strength-Figure 2 compares test-prediction ratios to concrete strength for splice specimens containing limestone and basalt coarse aggregate. The best-fit lines are based on a dummy variable regression analysis that limits the effect of the different number of tests carried out for normal and high-strength concrete with each aggregate. The best-fit lines are nearly horizontal, and the intercept of the line for specimens containing basalt is approximately $15 \%$ greater than that for the specimens containing limestone.

Because the predictions used are based on Eq. (1), these observations illustrate that, on average for the specimens shown, $f_{c}^{\prime 1 / 4}$ provides an unbiased representation of the effect of concrete strength on bond and, as demonstrated in Table 3, stronger coarse aggregates produce higher splice strengths. A comparison of test/prediction ratio versus $f_{c}^{\prime}$ for all 177 specimens used to develop Eq. (1) also produces a horizontal best-fit line (Zuo and Darwin, 1998). In contrast, if Eq. (1) is replaced by an expression based on $\sqrt{ } f_{c}^{\prime}$, the best-fit lines (for both the data shown in Fig. 2 and the full database) slope sharply down, indicating that such a relationship progressively overpredicts bond strength as $f_{c}^{\prime}$ increases.

\section{Effects of concrete properties on splices with transverse reinforcement}

To investigate the effects of concrete properties on the strength of splices confined by transverse reinforcement, the additional bond force due to confinement provided by transverse reinforcement $T_{s}$ is obtained by subtracting $T_{c}$ (calculated using Eq. (1)) from the experimentally determined total bond force $T_{b}$. Initially, comparisons of $T_{s} / f_{c}^{\prime}{ }^{1 / 4}$ with $N A_{t r} / n$ are used to evaluate the effect of concrete properties on $T_{s}$ for the specimens tested in this study, plus those tested by Hester (1993) and Darwin et al. (1996a).

Effect of coarse aggregate-Figure 3 compares $T_{s} / f_{c}^{\prime 1 / 4}$ versus $t_{r} N A_{t r} / n$ for No. 8 (No. 25) conventional bar splices in normal and high-strength concretes containing normal and high quantities of limestone coarse aggregate. The term $t_{r}=$ $9.6 R_{r}+0.28$ (Darwin et al. 1996a) represents the observed

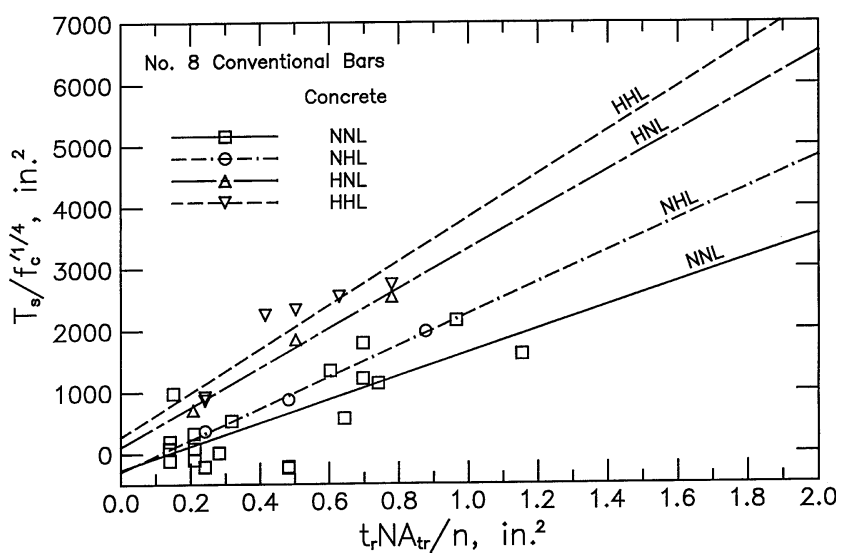

Fig. 3-Increase in bond force $\mathrm{T}_{\mathrm{s}}$ normalized with respect to $\mathrm{f}_{\mathrm{c}}^{\prime}{ }^{\prime 1 / 4}$ versus $\mathrm{t}_{\mathrm{r}} \mathrm{NA}_{\mathrm{tr}} / \mathrm{n}$ for No. 8 (No. 25) conventional bars in normal $(N)$ and high-strength $(H)$ concrete containing normal $(N)$ quantities of limestone $(L)$ coarse aggregate, showing contributions to splice strength as function of concrete strength and quantity of coarse aggregate $(1 \mathrm{in} .=$ $25.4 \mathrm{~mm})$.

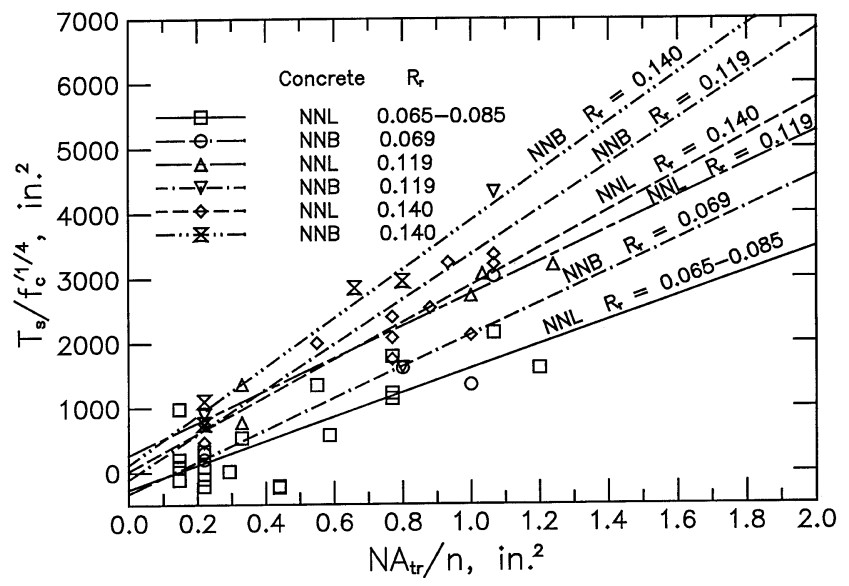

Fig. 4-Increase in bond force $\mathrm{T}_{\mathrm{s}}$ normalized with respect to $\mathrm{f}_{\mathrm{c}}^{\prime}{ }^{1 / 4}$ versus $\mathrm{NA}_{\mathrm{tr}} / \mathrm{n}$ for No. 8 (No. 25$)$ conventional bars in normal $(N)$ and high-strength $(H)$ concrete containing normal $(N)$ quantities of coarse aggregate, as affected by coarse aggregate type (basalt [B] or limestone [L]) and relative rib area $(1 \mathrm{in} .=25.4 \mathrm{~mm})$.

effect of relative rib area on $T_{s}$. Using $t_{r}$ as a parameter eliminates the effect of small differences in relative rib area $\left(R_{r}\right.$ ranges from 0.065 to 0.085 ) from the analysis.

Figure 3 shows that $T_{s} / f_{c}^{\prime 1 / 4}$ is higher for concretes containing high quantities of coarse aggregate (NHL and HHL) than for the concretes containing normal quantities (NNL and HNL), demonstrating that the quantity of coarse aggregate can have a measurable effect on $T_{s}$.

$T_{s} / f_{c}^{\prime 1 / 4}$ is compared with $N A_{t r} / n$ in Fig. 4 for conventional and high $R_{r}$ No. 8 (No. 25) bars cast in normal strength concretes containing normal quantities of limestone and basalt coarse aggregate. Note that $t_{r}$ is not used as a parameter in this comparison. The figure shows that $T_{s} / f_{c}^{\prime}{ }^{1 / 4}$ is higher, the higher the relative rib area of the bar. The figure also shows that, for all bar patterns, $T_{s} / f_{c}^{\prime}{ }^{1 / 4}$ is higher for concrete containing basalt than for concrete containing limestone, matching the earlier observations (Darwin et al. 1996a). Similar results are obtained in the current study for bars cast in high-strength concrete (Zuo and Darwin 1998). 


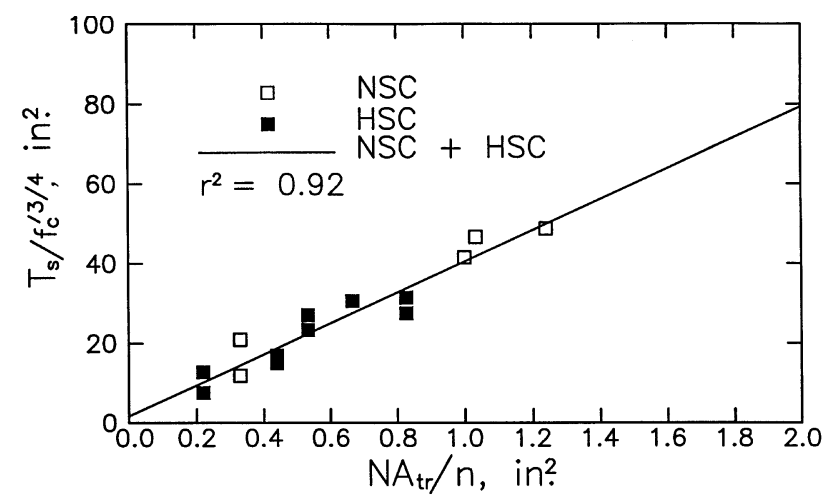

(a)

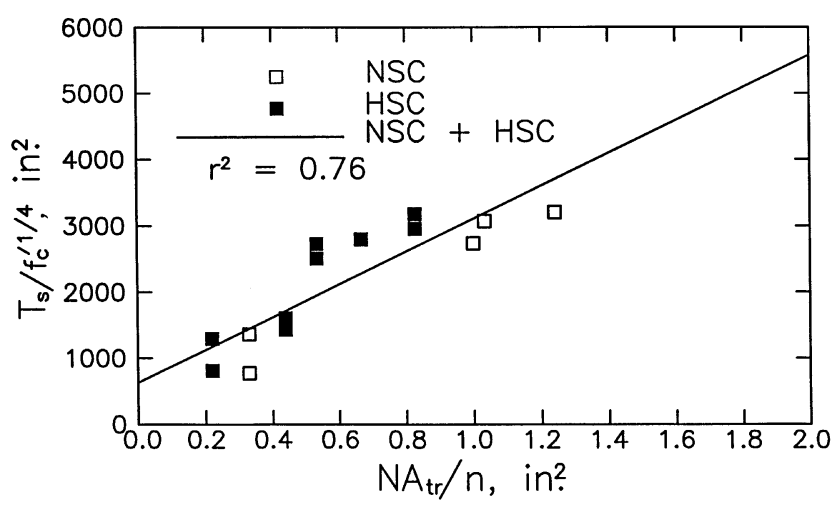

(b)

Fig. 5-Increase in bond force due to transverse reinforcement $\mathrm{T}_{\mathrm{s}}$ normalized with respect to $\mathrm{f}_{\mathrm{c}}^{\prime}{ }^{\mathrm{p}}$ versus $\mathrm{NA}_{\mathrm{tr}} / \mathrm{n}$ for No. 8 (No. 25) high relative rib area bars (8N3): (a) $\mathrm{p}=3$ / 4; and $(b) \mathrm{p}=1 / 4(1$ in. $=25.4 \mathrm{~mm})$.

Effect of concrete strength for current tests-Figure 3 shows that, for conventional bars, $T_{s} / f_{c}^{\prime 1 / 4}$ is higher for high-strength concrete than for normal strength concrete. Similar results are obtained for high $R_{r}$ bars (Zuo and Darwin 1998). These observations indicate that a power of $f_{c}^{\prime}$ greater than $1 / 4$ is needed to accurately characterize the effect of concrete strength on $T_{s}$.

To capture what might be referred to as the main behavior, powers $p$ of $f_{c}^{\prime}$ equal to $1 / 4,1 / 2,3 / 4$, and 1.0 were evaluated. To limit the number of variables, comparisons were initially made only for members containing limestone coarse aggregate. The test results for No. 8 and 11 (No. 25 and 36) high $R_{r}$ bars, $8 \mathrm{~N} 3\left(R_{r}=0.119\right)$ and 11F3 $\left(R_{r}=\right.$ 0.127 ), and No. 8 (No. 25) conventional bars were used for this purpose. For each bar, $T_{s}$ normalized with respect to $f_{c}^{\prime} p$ is plotted versus $N A_{t r} / n$, as illustrated for $8 \mathrm{~N} 3$ bars and two values of $p$ in Fig. 5a and 5b. The best-fit lines for each value of $p$ are then determined.

In general, the closer the coefficient of determination $r^{2}$ is to 1.0 for a best-fit line, the better the correlation between $T_{s} f_{c}^{\prime}{ }^{p}$ and $N A_{t r} / n$, which, in turn, indicates the better value of $p$ to characterize the effect of concrete strength on $T_{s}$. The values of $r^{2}$ for the different values of $p$ are summarized in Table 4 . The results show that $p=3 / 4$ produces the highest $r^{2}$ for the high $R_{r}$ bars: $r^{2}=0.92$ for $8 \mathrm{~N} 3$ bars, and $r^{2}=0.66$ for 11F3 bars. $p=1.0$ produces the highest $r^{2}(0.71)$ for the conventional No. 8 (No. 25) bars. For all three bar patterns, $p=1 / 4$ produces the lowest $r^{2}$ values ( 0.76 for $8 \mathrm{~N} 3$ bars, 0.57 for $11 \mathrm{~F} 3$ bars, and 0.48 for conventional No. 8 [No. 25] bars).
Table 4-Coefficients of determination $r^{2}$ for bestfit lines of $T_{s} / f_{c}^{\prime}$ versus $N A_{t r} / n$ for high relative rib area and conventional bars

\begin{tabular}{c|c|c|c|c|c|c}
\hline \multirow{2}{*}{ Bar designation $^{*}$} & \multicolumn{2}{|c|}{ No. of tests } & \multicolumn{4}{c}{$r^{2}$} \\
\cline { 2 - 7 } & NSC $^{\dagger}$ & HSC $^{\ddagger}$ & $p=1 / 4$ & $p=1 / 2$ & $p=3 / 4$ & $p=1$ \\
\hline Conventional No. 8 & 23 & 9 & 0.48 & 0.58 & 0.66 & 0.71 \\
\hline 8N3 & 5 & 10 & 0.76 & 0.90 & 0.92 & 0.87 \\
\hline 11F3 & 11 & 2 & 0.57 & 0.63 & 0.66 & 0.66 \\
\hline
\end{tabular}

*Notation of bar designation is same as in Table 2 .

${ }^{\dagger}$ Normal strength concrete containing coarse aggregate; $f_{c}^{\prime}<8000 \mathrm{psi}$.

${ }^{+}$High-strength concrete containing limestone coarse aggregate; $8000 \mathrm{psi} \leq f_{c}^{\prime}<$ 16,000 psi.

Note: 1 psi $=6.895 \mathrm{kPa}$

Table $5-C_{1}, C_{2}, t_{p} t_{d}$, and $r^{2}$ for different values of $p$

\begin{tabular}{c|c|c|c|c|c}
\hline$p^{*}$ & $C_{1}$ & $C_{2}$ & $t_{r}$ & $t_{d}$ & $r^{2 \dagger}$ \\
\hline $1 / 4$ & 1977 & 455 & $7.9 R_{r}+0.41$ & $0.87 d_{b}+0.13$ & 0.787 \\
\hline $1 / 2$ & 247 & 40.4 & $8.8 R_{r}+0.34$ & $0.83 d_{b}+0.17$ & 0.836 \\
\hline $3 / 4$ & 30.9 & 3.59 & $9.6 R_{r}+0.28$ & $0.78 d_{b}+0.22$ & 0.858 \\
\hline 1.0 & 3.823 & 0.322 & $10.3 R_{r}+0.23$ & $0.73 d_{b}+0.27$ & 0.860 \\
\hline
\end{tabular}

* Power of concrete compressive strength $f_{c}^{\prime}$ used to normalize additional bond force provided by transverse reinforcement $T_{s}$.

${ }^{\dagger}$ Coefficient of determination of best-fit line.

$T_{s} / f_{c}^{\prime}{ }^{p}$ for $8 \mathrm{~N} 3$ bars is plotted versus $N A_{t r} / n$ in Fig. 5(a) and (b) for $p=3 / 4$ and $1 / 4$, respectively. The figures show that when $T_{s}$ is normalized with respect to $f_{c}^{\prime}{ }^{3 / 4}$, the data points for high-strength and normal strength concrete overlap, resulting in a higher value of $r^{2}$. When $T_{s}$ is normalized with respect to $f_{c}^{\prime 1 / 4}$, the normalized bond forces are higher for high-strength concrete than for normal strength concrete.

Effect of concrete strength using database-Overall, the best power of $f_{c}^{\prime}$ to characterize the effect of concrete strength on $T_{s}$ involves consideration of two other variables: bar diameter $d_{b}$, and relative rib area $R_{r}$. Following procedures used by Darwin et al. (1996a), an analysis was performed (Zuo and Darwin 1998) with a database consisting of 163 development and splice tests from the U.S. and Canada (Mathey and Watstein 1961; Ferguson and Breen 1965; Thompson et al. 1975; Zekany et al. 1981; DeVries et al. 1991; Hester et al. 1993; Rezansoff et al. 1991, 1993; Azizinamini 1995; Darwin et al. 1996a; and Zuo and Darwin 1998). The linear relationships producing the best match with the data for each value of $p$ are expressed as

$$
\frac{T_{s}}{f_{c}^{\prime}}=C_{1}\left(t_{r} t_{d}\right) \frac{N A_{t r}}{n}+C_{2}
$$

The coefficients, $C_{1}, C_{2}, t_{r}$, and $t_{d}$, and the coefficients of determination $r^{2}$ are summarized in Table 5 for the four values of $p$. In each case, $t_{r}$ increases linearly with relative rib area, and $t_{d}$ increases linearly with bar diameter. $r^{2}$ is highest $(0.860)$ for $p=1.0 . r^{2}(0.858)$ is just slightly lower for $p=3 / 4 . p=1 / 4$ produces the lowest value of $r^{2}(0.786)$.

As the next step, for each value of $p$, Eq. (2) is combined with Eq. (1) to obtain predicted strengths. The predicted strengths and test-prediction ratios for the 163 specimens are summarized in Table A.6 of Appendix A. The average of the test-prediction

\footnotetext{
*The Appendix is available in xerographic or similar form from ACI headquarters, where it will be kept permanantly on file, at a charge equal to the cost of reproduction
} plus handling at the time of request. 
ratios is 1.0 for all four values of $p$. The least scatter in the results, as indicated by the COV, is obtained for $p=1 / 2$, for which the $\mathrm{COV}=0.116$. $p=3 / 4$ and $p=1 / 4$ provide COVs of 0.120 and 0.122 , respectively; while $p=1.0$ has the highest $\mathrm{COV}$ (0.132). The values of COV reflect the accuracy of the predictions for the overall database, while the values of $r^{2}$ reflect the goodness of fit between each expression and the data.

The best value of $p$ for characterizing the effect of concrete strength on $T_{S}$ should provide not only a low COV and a high $r^{2}$, but unbiased predictions for both normal and high-strength concrete. This means that, for the appropriate value of $p$, the best-fit line of the test-prediction ratio versus $f_{c}^{\prime}$ should be horizontal. The best-fit lines for the four values of $p$ are plotted in Fig. 6(a). The figure shows that the slope of the lines decreases with an increase in the value of the power of $p$. $p=3 / 4$ gives the smallest positive slope and a line that is nearly horizontal, while $p=1.0$ gives a negative slope. Thus, of the four values of $p, p=3 / 4$ gives the least biased predictions of bond strength based on concrete strength. $p=1.0$ overestimates bond strength for bars in high-strength concrete. The results in Fig. 6(a) suggest that the best value of $p$ may be slightly higher than 0.75 .

As another check on the value of $p$ and the accuracy of Eq. (1) and (2), an independent set of 33 splice specimens tested by Kadoriku (1994) was analyzed. For this series, $f_{c}^{\prime}$ ranged from 3070 to $10,980 \mathrm{psi}(21.2$ to $75.7 \mathrm{MPa})$, and a single bar diameter of $19 \mathrm{~mm}$ was used. Because $R_{r}$ was not reported, a value of $R_{r}$ $=0.748$ (the mean value for No. $6[19 \mathrm{~mm}]$ conventional bars [Darwin 1996b]) is used. The analysis (summarized in Table A.7 of Appendix $A^{*}$ ) indicates that $p=3 / 4$ provides the lowest COV $(0.085)$ for the 33 specimens. The best-fit lines for testprediction ratios using the four values of $p$ are plotted versus $f_{c}^{\prime}$ in Fig. 6(b), and show the same characteristics as in Fig. 6(a): $p$ $=3 / 4$ provides a nearly horizontal line, with the smallest positive slope, while $p=1.0$ gives a negative slope. Thus, among the values of $p$ evaluated, $p=3 / 4$ is the most appropriate for use in characterizing the effect of concrete strength on $T_{s}$. For simplicity and convenience, $p=3 / 4$, (rather than a possibly more precise, slightly higher value) is selected for the next step.

\section{DESIGN EXPRESSIONS}

To take full advantage of the data available, the 33 tests by Kadoriku (1994) are combined with the initial 163 tests to obtain a best-fit expression for the contribution of transverse reinforcement to splice strength

$$
\frac{T_{s}}{f_{c}^{\prime 3 / 4}}=31.14 t_{r} t_{d} \frac{N A_{t r}}{n}+3.99
$$

with $r^{2}=0.856$.

Combining Eq. (1) with (3) gives an expression for total bond force

$$
\begin{gathered}
\frac{T_{b}}{f_{c}^{\prime 1 / 4}}=\frac{T_{c}+T_{s}}{f_{c}^{\prime 1 / 4}}=\frac{A_{b} f_{s}}{f_{c}^{\prime 1 / 4}}= \\
{\left[59.81_{d}\left(c_{\text {min }}+0.5 d_{b}\right)+2350 A_{b}\right]\left(0.1 \frac{c_{\text {max }}}{c_{\text {min }}}+0.9\right)} \\
+\left(31.14 t_{r} t_{d} \frac{N A_{t r}}{n}+3.99\right) f_{c}^{\prime 1 / 2}
\end{gathered}
$$

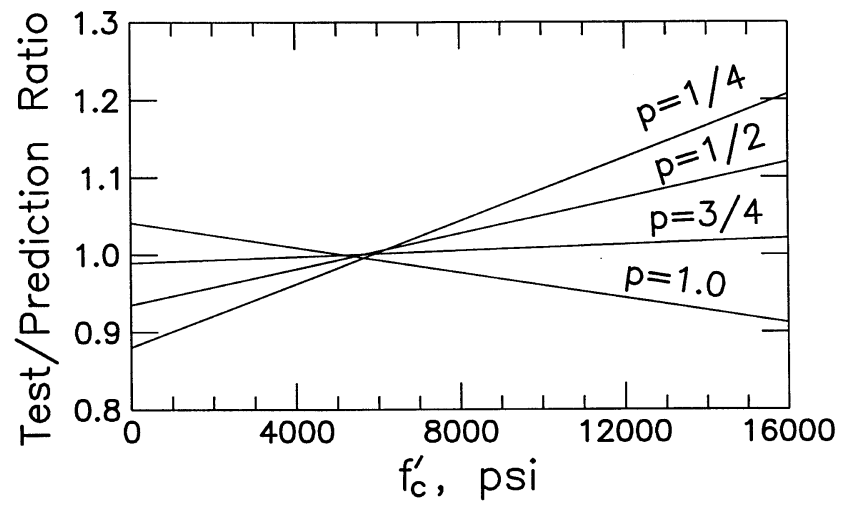

(a)

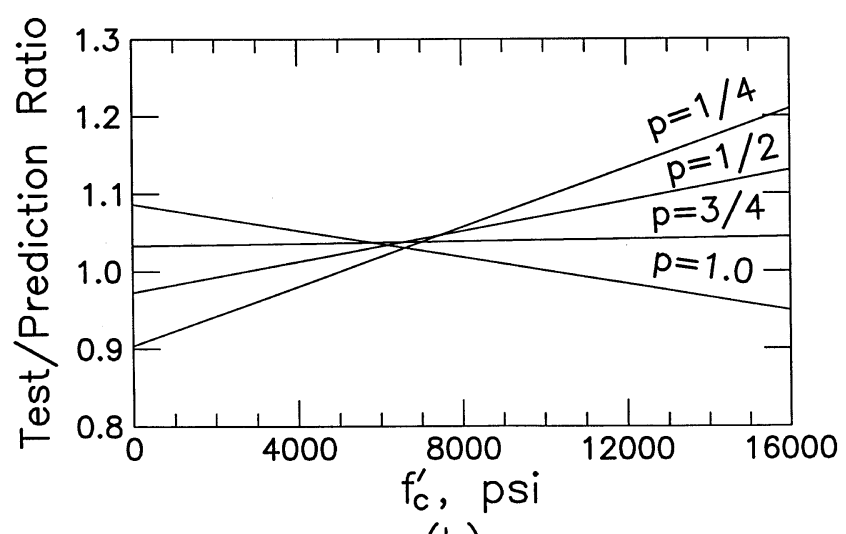

(b)

Fig. 6-Best-fit lines for test-prediction ratios corresponding to powers of $\mathrm{f}_{\mathrm{c}}^{\prime}(\mathrm{p}=1 / 4,1 / 2,3 / 4$, and 1.0), versus compressive strength $\mathrm{f}_{\mathrm{c}}^{\prime}$ : (a) initial comparison; and (b) independent comparison for specimens tested by Kadoriku (1994) $(1 \mathrm{psi}=6.89 \mathrm{kPa})$.

A comparison of the test and predicted strengths for the beams in the database in which the bars are confined by transverse reinforcement is presented in Table A.8 of Appendix $A^{*}$ and Fig. 7. The mean is 1.00 , and the COV is 0.115. (By way of comparison, Darwin et al. [1996b] obtained values of 1.01 and 0.125 .)

Dropping the intercept 3.99 in Eq. (4), substituting $l_{d} / s$ for $N$, where $s=$ stirrup or tie spacing, and solving for development/splice length $l_{d}$ in terms of $A_{b}$ and $d_{b}$, respectively, gives

$$
\begin{gathered}
l_{d}=\frac{A_{b}\left[\frac{f_{s}}{f_{c}^{\prime 1 / 4}}-2350\left(0.1 \frac{c_{\text {max }}}{c_{\text {min }}}+0.9\right)\right]}{59.8\left[\left(c_{\text {min }}+0.5 d_{b}\right)\left(0.1 \frac{c_{\max }}{c_{\text {min }}}+0.9\right)+0.52 \frac{t_{r} t_{d} A_{t r}}{s n} f_{c}^{\prime 1 / 2}\right]} \\
\frac{l_{d}}{d_{b}}=\frac{\frac{f_{s}}{f_{c}^{\prime 1 / 4}}-2350\left(0.1 \frac{c_{\text {max }}}{c_{\text {min }}}+0.9\right)}{76.1\left(\frac{c+K_{t r}}{d_{b}}\right)}
\end{gathered}
$$

\footnotetext{
${ }^{*}$ The Appendix is available in xerographic or similar form from ACI headquarters, where it will be kept permanantly on file, at a charge equal to the cost of reproduction plus handling at the time of request.
} 


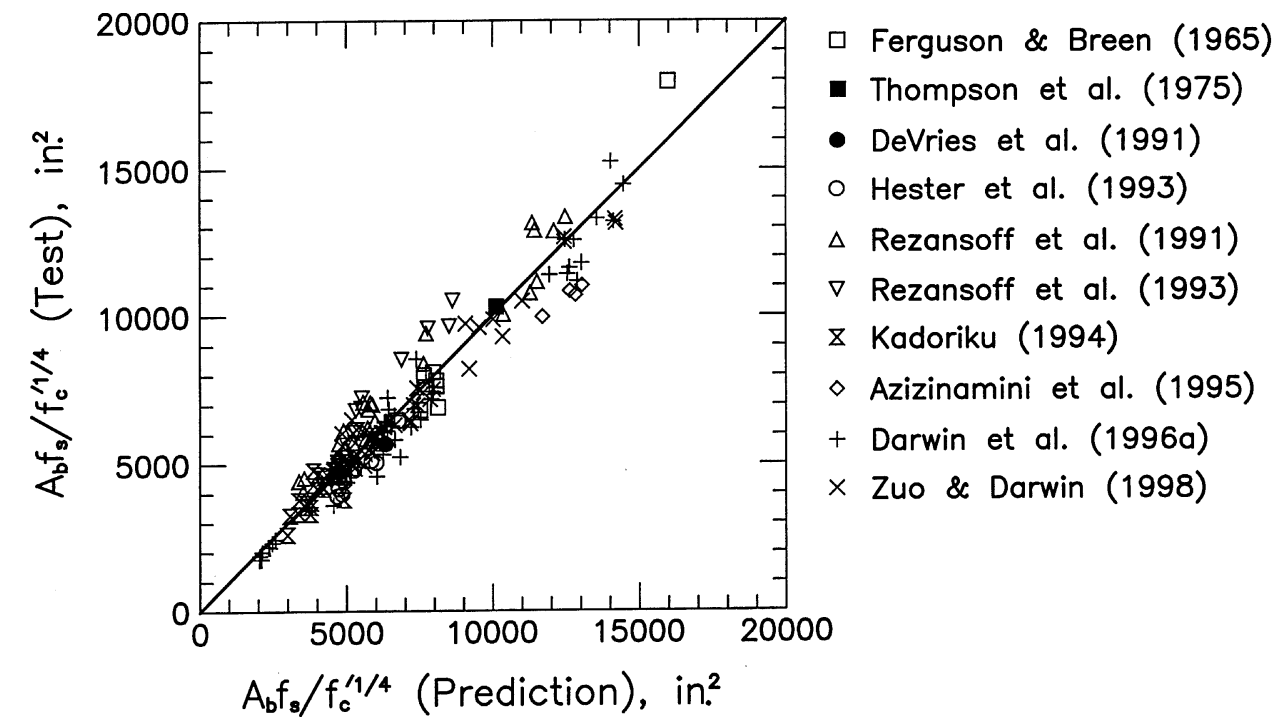

Fig. 7-Experimental bond force $\mathrm{T}_{\mathrm{b}}=\mathrm{A}_{\mathrm{b}} \mathrm{f}_{\mathrm{s}}$ normalized with respect to $\mathrm{f}_{\mathrm{c}}^{\prime 1 / 4}$ versus predicted bond strength, based on Eq. (4) (1 in. $=25 \mathrm{~mm})$.

in which $K_{t r}=\left(0.52 t_{r} t_{d} A_{t r} / s n\right) f_{c}^{\prime 1 / 2}, t_{r}=9.6 R_{r}+0.28, t_{d}=$ $0.78 d_{b}+0.22, l_{d} / d_{b} \geq 16, c=\left(c_{\text {min }}+0.5 d_{b}\right)\left(0.1 c_{\text {max }} / c_{\text {min }}+\right.$ $0.9)$ and $\left(c+K_{t r}\right) / d_{b} \leq 4.0 . c_{\max }$ and $c_{\text {min }}$ are defined following Eq. (1). For conventional bars, the average value of $R_{r}$ is 0.0727 (Darwin et al. 1996a, 1996b), which allows $K_{t r}$ to be expressed in a somewhat simpler and slightly conservative form as $K_{t r}=\left(0.5 t_{d} A_{t r} / s n\right) f_{c}^{\prime}{ }^{1 / 2}$. The limits on $l_{d} / d_{b}$ and $(c+$ $\left.K_{t r}\right) / d_{b}$ insure that a splitting failure, rather than a pullout failure, will govern bond strength (Darwin et al. 1996b; and Zuo and Darwin 1998).

The final step required to convert Eq. (6) to a design expression involves the application of a strength reduction $\phi$ factor. Using the LRFD approach described by Darwin et al. (1998), a value of $\phi=0.90$ is obtained (Zuo and Darwin 1998), matching the value calculated by Darwin et al. (1998) using a smaller database.

Multiplying the right side of Eq. (4) by 0.9, setting $f_{s}=f_{y}$, and solving for $l_{d} / d_{b}$ gives

$$
\frac{l_{d}}{d_{b}}=\frac{\frac{f_{y}}{f_{c}^{\prime 1 / 4}}-2100\left(0.1 \frac{c_{\text {max }}}{c_{\text {min }}}+0.9\right)}{68\left(\frac{c+K_{t r}}{d_{b}}\right)}
$$

For design purposes, Eq. (7) can be conservatively simplified by setting $c_{\max } / c_{\min }=1.0$ and dropping the 0.25 term in the definition of the effective value of $c_{s i}$ (refer to Eq. (1)), which gives

$$
\frac{l_{d}}{d_{b}}=\frac{\frac{f_{y}}{f_{c}^{\prime 1 / 4}}-2100}{68\left(\frac{c+K_{t r}}{d_{b}}\right)}
$$

Equations (7) and (8) may be applied for bottom-cast developed and spliced bars in normalweight concrete (Darwin et al. 1996b, 1998; and Zuo and Darwin 1998). Because the database used to develop the expressions consists of $90 \%$ splice specimens and $10 \%$ development length specimens, the 1.3 factor for Class B splices used in ACI 318-99 is not needed. The two equations are similar to the equations developed by Darwin et al. (1996b); the expressions differ in the values of the constants in the numerator and denominator ( 2100 versus 1900 and 68 versus 72, respectively) and the definition of $K_{t r}$ (Darwin et al. [1996b] used $K_{t r}=35.5 t_{r} t_{d} A_{t r}$ l $s n)$. In the earlier work, the $1 / 4$ power of $f_{c}^{\prime}$ was used to characterize the effect of concrete strength on $T_{s}$, based on a database that included only a small number of specimens cast with high-strength concrete. Because the $1 / 4$ power of $f_{c}^{\prime}$ is the same as used to normalize $T_{c}$, the earlier $K_{t r}$ term is a function only of bar size, relative rib area, and confining transverse reinforcement. The two values of $K_{t r}$ are equal for $f_{c}^{\prime}=4660$ psi $(32 \mathrm{MPa})$.

\section{COMPARISON WITH ACI 318-99}

Equations (7) and (8) are generally similar in format to Eq. (12-1) in ACI 318-99, which for bottom-cast, uncoated bars in normalweight concrete is

$$
\frac{l_{d}}{d_{b}}=\frac{3}{40} \frac{f_{y}}{\sqrt{f_{y}^{\prime}}} \frac{\gamma}{\left(\frac{c+K_{t r}}{d_{b}}\right)}
$$

in which $\gamma=0.8$ for No. 6 (No. 19) and smaller bars and = 1.0 for No. 7 (No. 22) and larger bars, $K_{t r}=A_{t r} f_{y t} /(1500 s n)$, $f_{y t}=$ yield strength of transverse reinforcement, $c$ is as defined for Eq. (8), and $\left(c+K_{t r}\right) / d_{b} \leq 2.5$.

The application of Eq. (9) differs from the application of Eq. (7) and (8) in three ways: 1) Eq. (9) distinguishes No. 6 (No. 19) and smaller bars from larger bars using the $\gamma$ term, leading to a $20 \%$ drop in development/splice length for the smaller bars; 2) the $K_{t r}$ term in Eq. (9) includes the yield strength of the transverse reinforcement $f_{y t}$, even though test results show that $f_{y t}$ has no effect on bond strength; and 3 ) the development length $l_{d}$ calculated using Eq. (9) must be increased by $30 \%$ for Class B splices (splices in which the area of steel provided is less than two times the area of steel required or where more than $50 \%$ of the steel is spliced). $l_{d}$ in Eq. (9) is used without modification for developed bars and Class A splices (splices for which the area of reinforcement provided is at least twice that required by analysis and $1 / 2$ or less of the total reinforcement is spliced). 


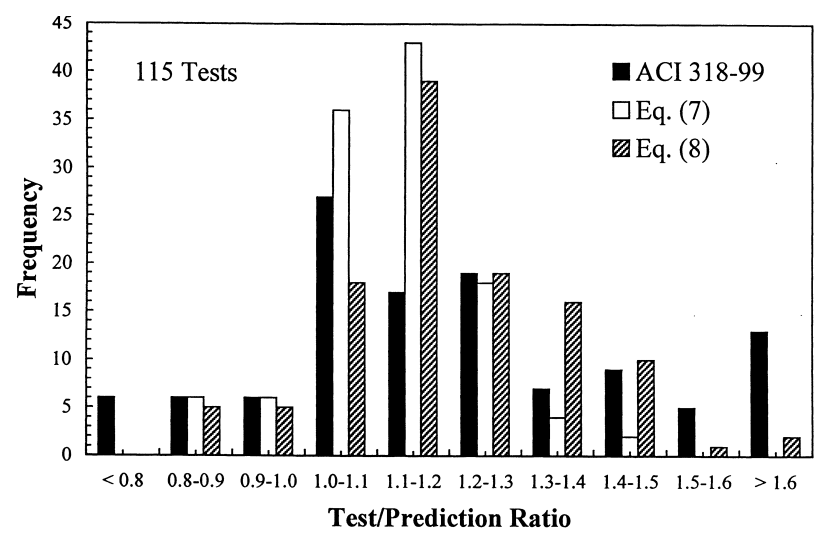

(a)

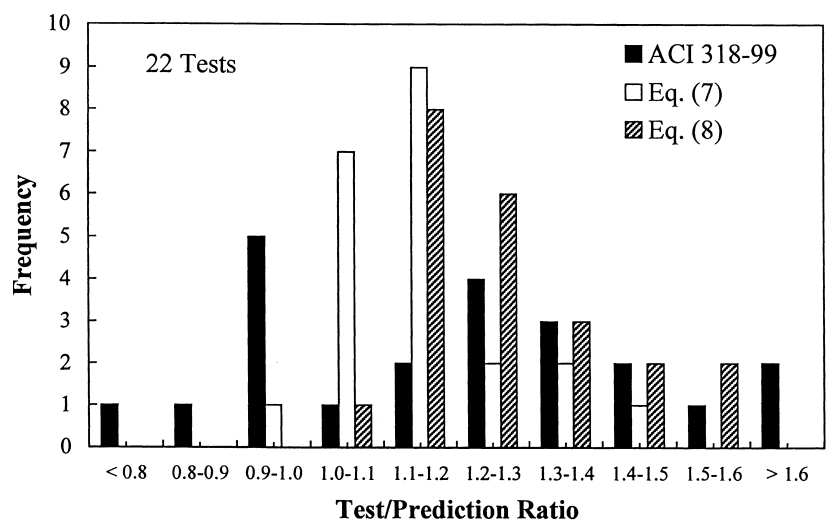

(b)

Fig. 8-Comparisons of test-prediction ratio distributions using ACI 318-99, Eq. (7) and Eq. (8) for specimens containing: (a) No. 7 (No. 22) and larger bars; and (b) No. 6 (No. 19) and smaller bars without confining transverse reinforcement.

The relative economy and safety of the ACI criteria and those represented by Eq. (7) and (8) can be obtained by comparing the strengths predicted by the equations with test results in the database maintained by ACI Committee 408. Because of the effect of $R_{r}$ on $K_{t r}$ (Eq. (7) and (8)), only tests of conventional reinforcement are used for bars confined by transverse reinforcement. The comparisons are presented in Tables A.9 and A.10 of Appendix A ${ }^{*}$ and summarized in Table 6 and Fig. 8 and 9. The predicted strengths do not include the 1.3 Class B splice length factor required by ACI 318-99, and the comparisons for Eq. (7) and (8) are made using $K_{t r}=$ $\left(0.5 t_{d} A_{t r} / s n\right) f_{c}^{\prime}{ }^{1 / 2}$. Comparisons are limited to test specimens with development/splice lengths $\geq 12$ in. and, for bars confined by transverse reinforcement, $l_{d} / d_{b} \geq 16$. Separate results are presented for No. 7 (No. 22) and larger bars and No. 6 (No. 19) and smaller bars to show the effect of the $\gamma$ factor. Overall, the comparisons with ACI 318 show greater scatter and a significantly greater number of low test-prediction ratios than those obtained with Eq. (7) or (8), especially for No. 6 (No. 19) and smaller bars.

\section{Bars without transverse reinforcement}

For No. 7 (No. 22) and larger bars without confining reinforcement (Fig. 8(a)), the test-prediction ratios range from 0.64 to 2.37 for ACI 318, compared with 0.85 to 1.45

\footnotetext{
*The Appendix is available in xerographic or similar form from ACI headquarters, where it will be kept permanantly on file, at a charge equal to the cost of reproduction plus handling at the time of request.
}

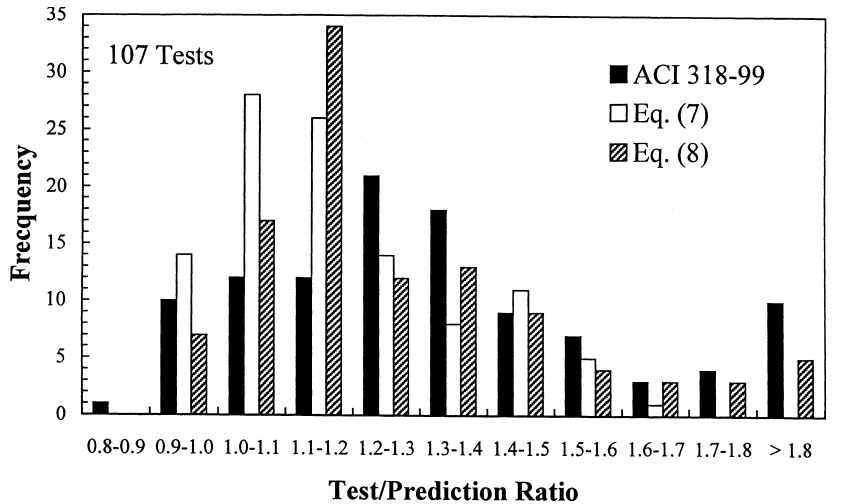

(a)

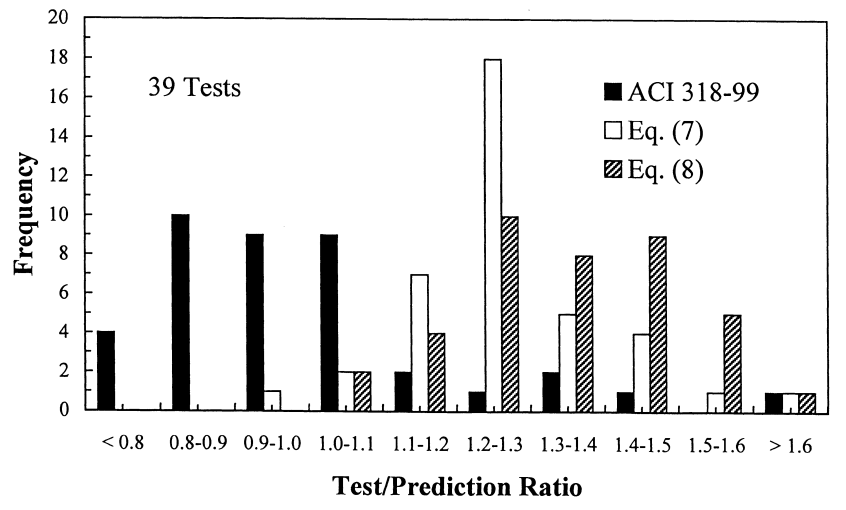

(b)

Fig. 9-Comparisons of test-prediction ratio distributions using ACI 318-99, Eq. (7) and Eq. (8) for specimens containing: (a) No. 7 (No. 22) and larger bars; and (b) No. 6 (No. 19) and smaller bars with confining transverse reinforcement.

for Eq. (7), and 0.85 to 1.73 for Eq. (8). The average test-prediction ratios are $1.22,1.12$, and 1.20 , which translates into slightly longer development and Class A splice lengths for ACI 318 than for Eq. (7) and (8). Because of the 1.3 factor, Class B splice lengths are considerably longer for ACI 318. In terms of safety, not only are the lowest test-prediction ratios much lower for ACI 318, but $16 \%$ of the test-prediction ratios are less than 1.0, compared with 10 and $9 \%$ for Eq. (7) and (8), respectively.

For No. 6 (No. 19) and smaller bars (Fig. 8(b)), the average test-prediction ratios range from 0.78 to $1.78($ mean $=1.22)$ for ACI 318, from 0.96 to 1.41 (mean = 1.15) for Eq. $(7)$, and from 1.08 to 1.55 (mean $=1.27$ ) for Eq. (8), indicating that, on average, ACI 318 development lengths are between the values for Eq. (7) and (8). In terms of safety, 32\% of the test specimens have test-prediction ratios less than 1.0 when evaluated based on ACI 318, compared with 5 and $0 \%$ for Eq. (7) and (8), respectively.

\section{Bars with transverse reinforcement}

For bars confined by transverse reinforcement, the testprediction ratios for No. 7 (No. 22) and larger bars (Fig. 9(a)) range from 0.85 to 2.19 (mean $=1.34$ ) for ACI 318, from 0.91 to 1.60 (mean $=1.18$ ) for Eq. $(7)$, and from 0.94 to 1.94 (mean $=1.26)$ for Eq. (8). In this case, ACI 318 requires greater average development lengths than Eq. (7) or (8). In terms of safety, $10 \%$ of the comparisons with ACI 318 have test-prediction ratios below 1.0, versus 13 and $7 \%$ for Eq. (7) and (8), respectively. 
Table 6-Test-prediction ratios obtained with ACI 318-99 (Eq. (9)) and proposed expressions (Eq. (7) and (8))

\begin{tabular}{|c|c|c|c|c|c|c|c|}
\hline & & \multirow{2}{*}{\multicolumn{3}{|c|}{$\begin{array}{c}\begin{array}{c}\text { Beams without transverse } \\
\text { reinforcement }\end{array} \\
\text { Test-prediction ratio } \\
\end{array}$}} & \multirow{2}{*}{\multicolumn{3}{|c|}{$\begin{array}{c}\begin{array}{c}\text { Beams with transverse } \\
\text { reinforcement }\end{array} \\
\text { Test-prediction ratio } \\
\end{array}$}} \\
\hline & & & & & & & \\
\hline & & $\frac{\text { Test }}{\text { ACI } 318}$ & $\frac{\text { Test }}{\text { Eq. (7) }}$ & $\frac{\text { Test }}{\text { Eq. (8) }}$ & $\frac{\text { Test }}{\text { ACI } 318}$ & $\frac{\text { Test }}{\text { Eq. (7) }}$ & $\frac{\text { Test }}{\text { Eq. (8) }}$ \\
\hline \multirow{5}{*}{$\begin{array}{l}\text { No. } 7 \text { (No. 22) } \\
\text { and larger bars }\end{array}$} & Maximum & 2.37 & 1.45 & 1.73 & 2.19 & 1.60 & 1.94 \\
\hline & Minimum & 0.64 & 0.85 & 0.85 & 0.85 & 0.91 & 0.94 \\
\hline & Average & 1.22 & 1.12 & 1.20 & 1.34 & 1.18 & 1.26 \\
\hline & $\mathrm{COV}$ & 0.24 & 0.10 & 0.14 & 0.23 & 0.14 & 0.18 \\
\hline & $\begin{array}{c}\text { Beams with } \\
\text { test-pred. }<1.0\end{array}$ & $16 \%$ & $10 \%$ & $9 \%$ & $10 \%$ & $13 \%$ & $7 \%$ \\
\hline \multirow{5}{*}{$\begin{array}{l}\text { No. } 6 \text { (No. } 19) \\
\text { and smaller bars }\end{array}$} & Maximum & 1.78 & 1.41 & 1.55 & 1.81 & 1.61 & 1.61 \\
\hline & Minimum & 0.78 & 0.96 & 1.08 & 0.70 & 0.94 & 1.07 \\
\hline & Average & 1.22 & 1.15 & 1.27 & 1.00 & 1.27 & 1.35 \\
\hline & $\mathrm{COV}$ & 0.22 & 0.10 & 0.11 & 0.21 & 0.10 & 0.11 \\
\hline & $\begin{array}{c}\text { Beams with } \\
\text { test-pred. }<1.0\end{array}$ & $32 \%$ & $5 \%$ & $0 \%$ & $59 \%$ & $3 \%$ & $0 \%$ \\
\hline
\end{tabular}

${ }^{*}$ For specimens with conventional reinforcement in ACI Committee 408 database.

Finally, for No. 6 (No. 19) and smaller bars with confining transverse reinforcement (Fig. 9(b)), the test-prediction ratios range from 0.70 to 1.81 (mean $=1.00)$ for ACI 318 , from 0.94 to 1.61 (mean $=1.27$ ) for Eq. (7), and from 1.07 to 1.61 (mean $=1.35$ ) for Eq. (8). The low average test-prediction ratio for ACI 318 is not a sign of economy, but results from the fact that $59 \%$ of the test-prediction ratios are less than 1.0. This compares with 3 and $0 \%$ for Eq. (7) and (8), respectively.

\section{Safety and economy}

The high percentage of test-prediction ratios less than 1.0 obtained with ACI 318-99 for No. 6 bars and smaller raises significant concerns for the level of safety provided by current design criteria for development/splice length, and demonstrates a lack of justification for using $\gamma=0.8$ for smaller bars. The comparisons also illustrate that application of Eq. (7) and (8) not only produce, on average, somewhat shorter development lengths and significantly shorter splice lengths than Eq. (9), but that they provide a safety margin that is superior to that provided by the criteria in ACI 318-99.

But why are there no failures?-The question arises as to why failures have not occurred if the safety margin is as low as indicated in this analysis for No. 6 (No. 19) and smaller bars. There are several reasons. First, ACI 318-99 requires that the development lengths calculated using Eq. (9) be increased by $30 \%$ for Class B splices. The extra splice length more than makes up for using $\gamma=0.8$. Second, for developed bars and Class A splices, structures are designed with load factors and capacity reduction factors for flexure, axial load, and shear that provide protection. Third, structures rarely see the values of live load specified in the statutory building codes. Happily, these factors help cushion the effects of the shorter development lengths for the smaller bars. The overall result is a smaller margin of safety for No. 6 (No. 19) and smaller bars than obtained for No. 7 (No. 22) and larger bars. Considering the large percentage of low test-prediction ratios, it would be wise to use $\gamma=1.0$ for all bar sizes.

\section{SUMMARY AND CONCLUSIONS}

Sixty-four splice specimens are used to investigate the effects of concrete properties on the splice strength of high relative rib area and conventional reinforcing bars. Bar relative rib areas range from 0.069 to 0.141 . Concrete mixtures with strengths ranging from 4250 to $15,650 \mathrm{psi}$ (29 to $108 \mathrm{MPa}$ ) and quantities of limestone and basalt coarse aggregate ranging from 1586 to $1908 \mathrm{lb} / \mathrm{yd}^{3}$ (941 to $1132 \mathrm{~kg} / \mathrm{m}^{3}$ ) are used. Test results from this study are combined with the results of previous studies.

Development/splice design equations are developed for uncoated reinforcing bars based on a database including 196 specimens containing bars confined by transverse reinforcement and 171 specimens containing bars not confined by transverse reinforcement. The design equations account for the effects of member geometry, bar size, relative rib area, confinement provided by transverse reinforcement, and concrete strength. A reliability-based strength reduction $\phi$ factor is incorporated in the design expressions. The design expressions are then compared with the development criteria in ACI 318-99 using the ACI Committee 408 database.

The following conclusions are based on the test results and analyses presented in this paper:

1. Concrete with stronger coarse aggregate provides higher splice strength under all conditions of confinement;

2. For splices confined by transverse reinforcement, the higher the quantity of coarse aggregate in the concrete, the greater the contribution of transverse reinforcement to splice strength;

3 . For splices not confined by transverse reinforcement, $f_{c}^{\prime 1 / 4}$ best characterizes the effect of concrete strength on splice strength. $f_{c}^{\prime 3 / 4}$ characterizes the effect of concrete strength on the additional splice strength provided by transverse reinforcement;

4. The splice strength of bars confined by transverse reinforcement increases with an increase in relative rib area and bar diameter;

5. The expressions characterizing the splice strength of reinforcing bars presented in this paper accurately represent the development/splice strength of bottom-cast uncoated bars as a function of member geometry, concrete strength, relative rib area, bar size, and confinement provided by both concrete and transverse reinforcement; and

6 . The new design expressions are superior to the design criteria in ACI 318-99 in terms of both safety and economy. The criteria in ACI 318-99 for developed bars and Class A splices are unconservative for No. 6 (No. 19) and smaller bars. 


\section{ACKNOWLEDGMENTS}

Support for this research was provided by the National Science Foundation under NSF Grants No. MSS-9021066 and CMS-9402563, the U.S. Department of Transportation-Federal Highway Administration, the Civil Engineering Research Foundation under CERF Contract No. 91-N6002, the Lester T. Sunderland Foundation, ABC Coating, Inc., AmeriSteel (formerly Florida Steel Corp.), Birmingham Steel Corp., Chaparral Steel, DuPont Powder Coatings, Fletcher Coating Co., North Star Steel Co., and 3M Corp. The basalt coarse aggregate was supplied by Geiger Ready-Mix and Iron Mountain Trap Rock Co. Form release agent, curing compound, and mounting hardware were supplied by Dayton Richmond.

\section{REFERENCES}

ACI Committee 318, 1999, "Building Code Requirements for Structural Concrete (ACI 318-99) and Commentary (318R-99)," American Concrete Institute, Farmington Hills, Mich., 391 pp.

ASTM A 615/A 615M-95b, 1996, "Standard Specification for Deformed and Plain Billet-Steel Bars for Concrete Reinforcement," 1996 Annual Book of ASTM Standards, V. 1.04, ASTM, West Conshohocken, Pa., pp. 302-307.

Azizinamini, A.; Stark, M.; Roller, J. H.; and Ghosh, S. K., 1993, "Bond Performance of Reinforcing Bars Embedded in High-Strength Concrete," ACI Structural Journal, V. 90, No. 5, Sept.-Oct., pp. 554-561.

Azizinamini, A.; Chisala, M.; Roller, J. H.; and Ghosh, S. K., 1995 "Tension Development Length of Reinforcing Bars Embedded in High-Strength Concrete," Engineering Structures, V. 17, No. 7, pp. 512-522.

Barham, S., and Darwin, D., 1999, "Effects of Aggregate Type, Water-to-Cementitious Material Ratio, and Age on Mechanical and Fracture Properties of Concrete," SM Report No. 56, University of Kansas Center for Research, Lawrence, Kans., Aug., 95 pp.

Chamberlin, S. J., 1956, "Spacing of Reinforcement in Beams," ACI JOURNAL, Proceedings V. 53, No. 1, July, pp. 113-134.

Chamberlin, S. J., 1958, "Spacing of Spliced Bars in Beams," ACI JOURNAL, Proceedings V. 54, No. 8, Feb., pp. 689-698.

Chinn, J.; Ferguson, P. M.; and Thompson, J. N., 1955, "Lapped Splices in Reinforced Concrete Beams," ACI JOURNAL, Proceedings V. 52, No. 2, Oct., pp. 201-214.

Choi, O. C.; Hadje-Ghaffari, H.; Darwin, D.; and McCabe, S. L., 1991 "Bond of Epoxy-Coated Reinforcement: Bar Parameters," ACI Materials Journal, V. 88, No. 2, Mar.-Apr., pp. 207-217.

Darwin, D., and Graham, E. K., 1993, "Effect of Deformation Height and Spacing on Bond Strength of Reinforcing Bars,"ACI Structural Journal, V. 90, No. 6, Nov.-Dec., pp. 646-657.

Darwin, D.; Tholen, M. L.; Idun, E. K.; and Zuo, J., 1996a, "Splice Strength of High Relative Rib Area Reinforcing Bars,"ACI Structural Journal, V. 93, No. 1, Jan.-Feb., pp. 95-107.

Darwin, D.; Zuo, J.; Tholen, M. L.; and Idun, E. K., 1996b, "Development Length Criteria for Conventional and High Relative Rib Area Reinforcing Bars, " ACI Structural Journal, V. 93, No. 3, May-June, pp. 347-359.

Darwin, D.; Idun, E. K.; Zuo, J.; and Tholen, M. L., 1998, "Reliabil-
ity-Based Strength Reduction Factor for Bond," ACI Structural Journal, V. 95, No. 4, July-Aug., pp. 434-443.

DeVries, R. A.; Moehle, J. P.; and Hester, W., 1991, "Lap Splice Strength of Plain and Epoxy-Coated Reinforcement," Report No. UCB/ SEMM-91/02, University of California, Berkeley, Calif., Jan., 86 pp.

Esfahani, M. R., and Rangan, B. V., 1996, "Studies on Bond between Concrete and Reinforcing Bars," School of Civil Engineering, Curtin University of Technology, Perth, Western Australia, $315 \mathrm{pp}$.

Ferguson, P. M., and Breen, J. E., 1965, "Lapped Splices for HighStrength Reinforcing Bars," ACI JOURNAL, Proceedings V. 62, No. 9, Sept., pp. 1063-1078.

Hatfield, E.; Azizinamini, A.; and Pavel, R., 1996, "Minimum Stirrup Requirements for Tension Splices in High-Strength Concrete," Abstract No. 130, 4th International Symposium on Utilization of High-Strength/ High-Performance Concrete, Paris, 10 pp.

Hester, C. J.; Salamizavaregh, S.; Darwin, D.; and McCabe, S. L., 1993, "Bond of Epoxy-Coated Reinforcement: Splices," ACI Structural Journal, V. 90, No. 1, Jan.-Feb., pp. 89-102.

Kadoriku, J., 1994, "Study on Behavior of Lap Splices in High-Strength Reinforced Concrete Members," PhD thesis, Kobe University, Mar., Japan, 201 pp.

Kozul, R., and Darwin, D., 1997, "Effects of Aggregate Type, Size, and Content on Concrete Strength and Fracture Energy," SM Report No. 43, University of Kansas Center for Research, Lawrence, Kans., June, 83 pp.

Maeda, M.; Otani, S.; and Aoyama, H., 1991, "Bond Splitting Strength in Reinforced Concrete Members," Transactions of the Japan Concrete Institute, V. 13, pp. 581-588.

Mathey, R. G., and Watstein, D., 1961. "Investigation of Bond in Beam and Pullout Specimens with High-Yield-Strength Deformed Bars," ACI JOURNAL, Proceedings V. 57, No. 9, Mar., pp. 1071-1090

Rezansoff, T.; Konkankar, U. S.; and Fu, Y. C., 1991, "Confinement Limits for Tension Lap Splices under Static Loading," Report, University of Saskatchewan, Saskatoon, Sask., Aug., 24 pp.

Rezansoff, T.; Akanni, A.; and Sparling, B., 1993, "Tensile Lap Splices under Static Loading: A Review of the Proposed ACI 318 Code Provisions," ACI Structural Journal, V. 90, No. 4, July-Aug. pp. 374-384.

Sakurada, T.; Morohashi, N.; and Tanaka, R., 1993, "Effect of Transverse Reinforcement on Bond Splitting Strength of Lap Splices," Transactions of the Japan Concrete Institute., V. 15, pp. 573-580.

Thompson, M.A.; Jirsa, J. O.; Breen, J. E.; and Meinheit, D. F., 1975, "The Behavior of Multiple Lap Splices in Wide Sections," Research Report No. 154-1, Center for Highway Research, The University of Texas at Austin, Feb., 75 pp.

Zekany, A. J.; Neumann, S.; and Jirsa, J. O., 1981, "The Influence of Shear on Lapped Splices in Reinforced Concrete," Research Report No. 242-2, Center for Highway Research, The University of Texas at Austin, July, 88 pp.

Zuo, J., and Darwin, D., 1998, "Bond Strength of High Relative Rib Area Reinforcing Bars," SM Report No. 46, University of Kansas Center for Research, Lawrence, Kans., Jan., 350 pp. 